\title{
GENDER BUKANTABU Catatan Perjalanan Fasilitasi Kelompok Perempuan di Jambi
}

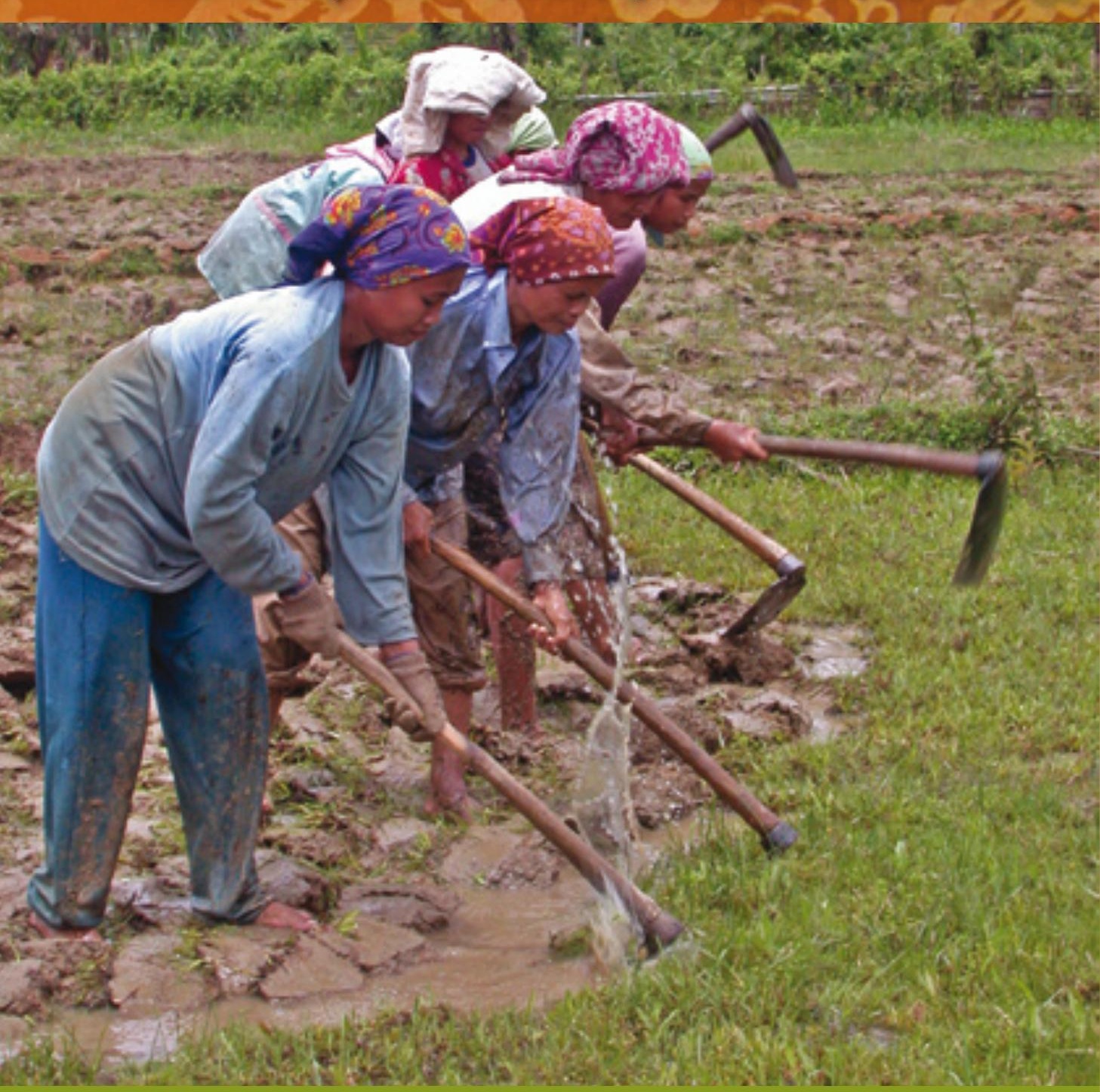





\section{GENDER BUKAN TABU \\ Catatan Perjalanan Fasilitasi Kelompok \\ Perempuan di Jambi}

Dede Wiliam-de Vries 
Buku ini diterbitkan sebagai bagian dari hasil penelitian berjudul "Collective Action to Secure Property Rights for the Poor:Avoiding Elite Capture of Natural Resource Benefits and Governance Systems" kerjasama antara CIFOR, CGIAR System-wide Program on Collective Action and Property Rights (CAPRi), International Food Policy Research Institute (IFPRI) dan Pemerintah Daerah Kabupaten Bungo dan Tanjung Jabung Barat, Provinsi Jambi

Perpustakaan Nasional: Katalog Dalam Terbitan (KDT)

Wiliam-de Vries, D.

Gender bukan tabu: catatan perjalanan fasilitasi kelompok perempuan di Jambi/by Dede Wiliam-de Vries. Bogor, Indonesia: Center for International Forestry Research (CIFOR), 2006.

ISBN: 979-24-4659-1

$58 \mathrm{hlm}$.

CABI thesaurus: 1.gender relations 2. rural women 3.woman's status 4. natural resources

5. resource management 6 .community action 7 .social participation

8. facilitation

9. Sumatra 10. Indonesia I.Title

@ 2006 oleh Center for International Forestry Research (CIFOR)

Foto sampul oleh Yentirizal

Ilustrasi oleh Wiyono

Desain dan tata letak oleh Vidya Fitrian

Diterbitkan oleh

Center for International Forestry Research (CIFOR)

Jl. CIFOR, Situ Gede, Sindang Barang

Bogor Barat 16680, Indonesia

Tel.: +62 (251) 622622; Fax:+62 (251) 622100

E-mail: cifor@cgiar.org

Situs web: http://www.cifor.cgiar.org 


\section{Daftar Isi}

Daftar Singkatan $\quad$ v

Kata Pengantar vi

Abstrak ix

\section{BAB 1}

Apakah Gender Melawan Kodrat?

1.1. Pengertian Seks, Gender dan Kodrat 3

1.2. Gender Tidak Melawan Kodrat 4

\section{BAB 2}

Bagaimana Peran Gender Berlaku di Masyarakat?

2.1. Kesetaraan Gender

2.2. Ketidakadilan Gender $\quad 12$

2.2.1. Penomorduaan (Subordinasi) 12

2.2.2. Pelabelan Negatif pada Perempuan (Stereotype) 15

2.2.3. Peminggiran (Marginalisasi) 17

2.2.4. Beban Kerja Berlebih (Multi-burdened) 20

2.2.5. Kekerasan 22

2.3. Sensitif Gender Diperlukan dalam Program-program Pembangunan Daerah 
BAB 3

Bagaimana Memfasilitasi Kelompok Perempuan?

3.1. Fasilitator $\quad 35$

3.2. Apakah Fasilitator Gender Harus Perempuan? 36

3.3. Mengenal Karakter Kelompok 38

3.4. Adakah Hal-hal Lain yang Perlu Diantisipasi jika Fasilitasi Telah Berjalan Sukses Saat Ini?

3.4.1. Ketergantungan yang Tinggi dari Kelompok Dampingan terhadap Fasilitator

3.5.2. Fasilitator Berubah menjadi Guru dan Narasumber

3.5.3. Fasilitator menjadi Misionaris

3.5.4. Munculnya 'Selebritis' dalam Kelompok

Penutup

Catatan Akhir 


\section{Daftar Singkatan}

CAPRi Collective Action and Property Rights, Aksi Kolektif dan Hak Properti

DPRD Dewan Perwakilan Rakyat Daerah

KDRT Kekerasan Dalam Rumah Tangga

KUT Kredit Usaha Tani

PKK Pemberdayaan Kesejahteraan Keluarga 


\section{Kata Pengantar}

Topik Gender bukan lagi merupakan hal yang baru bagi kalangan feminis, peneliti, akademisi, organisasi kemasyarakatan, pejabat pemerintahan maupun kalangan umum lainnya di masyarakat. Berbagai studi telah dilakukan untuk melihat hubungan yang kompleks antara Gender dengan isu-isu penting seperti politik, pendidikan, kesehatan, pengelolaan sumberdaya alam, dan lain sebagainya. Berbagai institusi dan lembaga baik dari sektor formal pemerintahan, LSM, lembaga penelitian, dan lain sebagainya beramai-ramai mengadakan training, kampanye, penelitian, survei dan berbagai program kegiatan lainnya yang berkaitan dengan Gender.

Pertanyaannya adalah sejauh mana inisiatif-inisiatif tersebut efektif mendukung upaya penguatan kapasitas perempuan di akar rumput? Apakah posisi dan peran Gender dalam masyarakat mengindikasikan adanya perubahan? Bagaimana posisi perempuan di dalam keluarga? Apakah perempuan mulai ikut terlibat secara aktif dalam proses pengambilan keputusan di institusi atau lembaga lokal?

Kebanyakan dari kita sering menolak kenyataan bahwa 'penerima manfaat program', yaitu perempuan-perempuan yang bergabung dalam 
kelompok yang difasilitasi (kelompok dampingan), selama ini masih berada pada tataran 'objek' penelitian, kelompok 'sasaran' atau pengikut setia dari kegiatan-kegiatan yang berkaitan dengan pemberdayaan perempuan. Hal ini seringkali terjadi karena program dan kegiatan yang ditawarkan (atau dipaksakan) pada kelompok dampingan tersebut lebih banyak diinisiasi oleh pihak luar (bukan berdasarkan ide yang digali dari komunitas itu sendiri). Dengan demikian, kelompok perempuan hanya mengikuti apa yang sudah tertulis dalam agenda si pemberi ide, tanpa mempunyai peluang untuk berpikir apakah kegiatan tersebut sesuai atau bertentangan dengan kepentingan mereka atau malah membuat masalah dengan kondisi lokal yang ada di sekitar mereka. Sayangnya, jika program kegiatan tidak berjalan sebagaimana yang diharapkan, kita serta merta 'menghakimi' bahwa program tersebut gagal, komunitas lokal tidak co-operative dalam berproses, kondisi lokal tidak mendukung atau bahkan menyalahkan fasilitator yang tidak bisa 'mendorong' kelompok dampingannya untuk berkembang sesuai dengan tujuan program. Pernahkah terpikir oleh kita bahwa mungkin 'kegagalan' dalam berproses tersebut kemungkinan adalah bentuk keberhasilan sistem lokal? Atau bahkan kegagalan tersebut memunculkan ide-ide brilian di dalam komunitas yang luput dari perhatian kita? Buku ini tidak mendiskusikan apa yang benar atau salah dalam perspektif Gender menurut pandangan lokal dan dunia luar. Gender dipandang sebagai opsi terbuka, yang bisa sangat berbeda perspektif dan implementasinya tergantung dari kondisi dan realitas lokal yang ada di lapangan.

Buku ini bukan manual ataupun panduan tentang Gender, melainkan berisi ulasan tentang kegiatan fasilitasi kelompok petani lokal di Jambi yang mana sangat berkaitan erat dengan isu Gender. Fakta-fakta yang dikemukakan merupakan hasil kegiatan studi tim CAPRi-CIFOR di Propinsi Jambi. Buku ini mengulas tentang posisi dan peran Gender dalam kaitannya dengan upaya memfasilitasi aksi kolektif dalam pengelolaan sumberdaya alam yang dibangun bersama di desa-desa yang didampingi program CAPRi.

Saya mengucapkan terima kasih kepada masyarakat Desa Sungai Telang, Kab. Bungo dan Desa Lubuk Kambing, Kab, Tanjung Jabung Barat 
yang jerih payah dan partisipasinya dalam kegiatan penelitian ini telah memberikan inspirasi bagi saya untuk menuangkan ide dan pemikiran dalam buku ini. Kepada kedua pemerintah daerah kabupaten, khususnya staf yang berkecimpung di bidang pemberdayaan perempuan, saya juga sampaikan ucapan terima kasih atas saran-saran dan dukungan datadata statistiknya. Akhirnya, saya sampaikan penghargaan kepada CAPRi sebagai pemberi dana dan kepada teman-teman CIFOR yang telah membantu penyelesaian buku ini.

Pada akhirnya, semoga buku ini dapat membantu praktisi dan fasilitator di lapangan untuk mengenal lebih jauh mengenai Gender dari segi praktis, terlepas dari perdebatan mengenai konsep, teori dan definisi, sehingga dapat membantu kelompok dampingannya mengenali aspekaspek ketimpangan Gender yang ada di lingkungan sekitarnya.

Assen, 30 Mei 2006

D.Wiliam-de Vries 


\section{Abstrak}

Mengetahui efektivitas suatu kegiatan aksi kolektif yang melibatkan perempuan, terutama pada struktur masyarakat yang terdiri dari berbagai latar belakang etnis, mungkin akan sangat sulit untuk dilakukan. Sejauh ini belum ada perangkat atau sistem baku yang dapat digunakan untuk mengukur tingkat partisipasi perempuan dalam pengelolaan sumberdaya alam lokal, misalnya. Suatu kegiatan aksi kolektif terkadang dianggap telah berhasil mencapai target program, jika prosentase keterlibatan dan keterwakilan komponen masyarakat lokal dalam kegiatan tersebut menunjukkan satu angka yang tinggi. Hal yang terlupakan adalah bahwa komponen masyarakat tersebut terbentuk dari dua unsur penting, yaitu perempuan dan laki-laki, yang memiliki kebutuhan, keinginan dan kepentingan yang beragam. Manakala suatu inisiatif pemberdayaan masyarakat menganggap dua komponen ini sebagai satu identitas tunggal, maka dapat dipastikan akan ada ketimpangan dalam distribusi manfaat, dimana program tersebut lebih memberdayakan satu unsur dibandingkan unsur lainnya. Pada kebanyakan kasus, laki-laki mendapatkan porsi lebih besar dari manfaat program-program kegiatan yang ada di masyarakat, dibandingkan dengan perempuan. Buku ini mengulas pendekatan praktis Gender dalam kegiatan aksi kolektif serta parameter-parameter sederhana yang dapat digunakan untuk mengukur tingkat keterlibatan 
dan keterwakilan perempuan dalam suatu program. Berbagai teknik fasilitasi kelompok perempuan juga dibahas secara mendetail di dalam buku ini untuk memberikan gambaran mengenai situasi yang mungkin dihadapi di lapangan ketika bekerja sama dengan kelompok perempuan, terutama di daerah-daerah dimana informasi-informasi mengenai Gender tidak tersedia ataupun keberadaan 'Ahli Gender' tidak memungkinkan. Berbagai data dan informasi yang ada di dalam buku ini didasarkan pada pengalaman lapangan dan hasil penelitian tim CAPRi di Propinsi Jambi.

Program kegiatan CAPRi pada dasarnya bertujuan untuk meningkatkan pastisipasi pemangku kepentingan lokal dalam pengelolaan sumberdaya alam. Untuk itu program kegiatannya juga memberikan porsi yang cukup besar dalam upaya penguatan kapasitas perempuan, upaya peningkatan akses dan hak-hak perempuan terhadap sumberdaya melalui pendampingan yang intensif terhadap kelompok-kelompok perempuan yang aktif terlibat dalam aksi kolektif. Selain memfasilitasi upaya-upaya membangun proses pengambilan keputusan yang inklusif di tingkat lokal, program kegiatan CAPRi juga terus mendukung ke arah penguatan sistem pengelolaan sumberdaya yang berbasis komunitas lokal. Untuk itulah, Gender merupakan salah satu komponen yang selalu menjadi pertimbangan penting dalam menganalisis setiap tahapan pencapaian tujuan program. 


\section{BAB 1 \\ Apakah Gender Melawan Kodrat?}

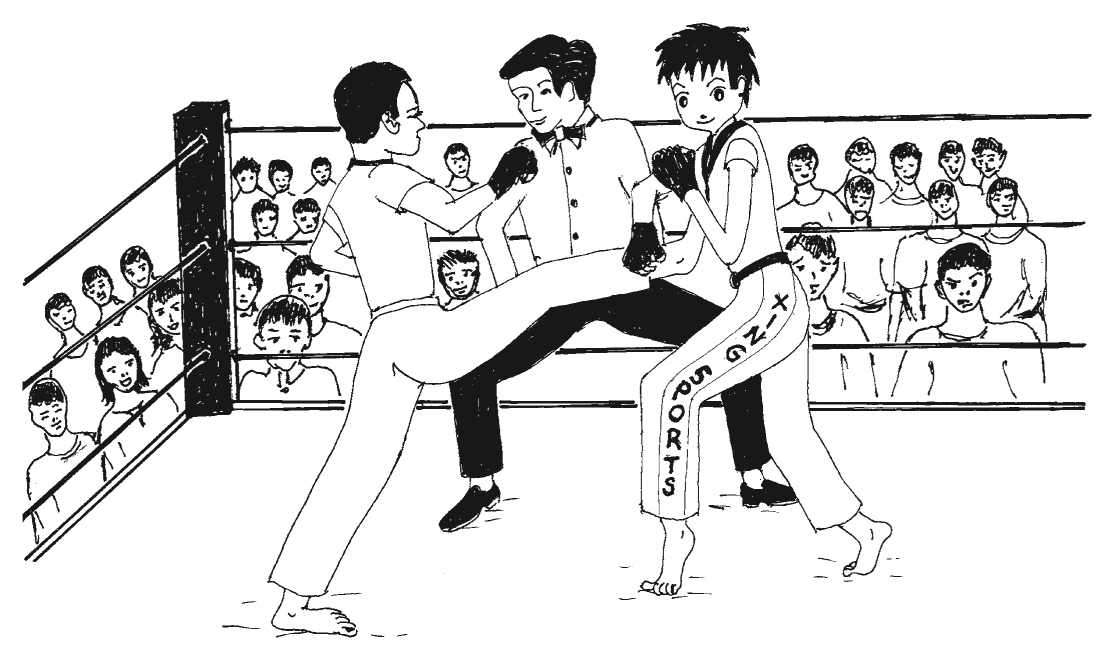

Gambar 1. Pertarungan antara perempuan dan laki-laki:

Inikah Gender?!@:?! 
Masih terekam dengan jelas di benak saya bagaimana reaksi terkejut masyarakat lokal di beberapa tempat ketika saya dengan anggota tim lainnya memfasilitasi diskusi terbuka tentang topik Gender. Pada satu jam pertama, sebagian besar dari mereka menunjukkan reaksi menolak, sungkan dan risih. Mereka berpendapat bahwa Gender adalah hal yang tabu, melawan kodrat dan tidak pantas dibicarakan di muka publik. Namun setelah satu jam berikutnya, kebanyakan dari mereka mulai bereaksi positif, terbuka, terlibat aktif dalam diskusi yang (pada kebanyakan kasus) berujung pada bahasan tentang ketidakadilan Gender yang terjadi di lingkungan mereka. Isu-isu umum yang berkaitan dengan Gender, seperti kekerasan dalam rumah tangga, tradisi, adat-istiadat dan berbagai problematika dalam hubungan bermasyarakat di tingkat lokal, muncul dengan sendirinya dan menjadi bahan diskusi hangat dalam forum tersebut. Pada akhir diskusi, topik Gender tidak lagi dianggap sesuatu yang aneh dan tabu untuk dibahas di muka umum.

Apa yang salah dengan satu jam pertama? Tidak ada yang salah. Yang terjadi adalah persepsi yang sempit dalam mengartikan peran Gender. Pemahaman akan arti dan makna Gender secara parsial (tidak utuh) dan tidak tuntas, kebanyakan adalah motor pemicu munculnya anggapan negatif komunitas lokal terhadap isu-isu Gender. Gender dianggap sebagai senjata beracun yang melawan adat dan tradisi. Gender dianggap pertarungan antar laki-laki dan perempuan. Mempermasalahkan persamaan Gender dianggap sama dengan melawan kodrat. Benarkah demikian?

Berangkat dari pengalaman tersebut, sebelum mendiskusikan lebih jauh tentang apa dan bagaimana Gender berpengaruh terhadap aspek-aspek sosial di sekitar kita, ada baiknya bagi kita memperjelas terlebih dahulu arti dan makna Gender itu sendiri, serta istilah-istilah lainnya yang sering dihubungkan dengan Gender. Dengan demikian kita bisa mendapatkan gambaran yang utuh tentang Gender dan tidak terjadi salah persepsi ketika mendiskusikan topik ini pada pembahasan-pembahasan selanjutnya. 


\subsection{Pengertian Seks, Gender dan Kodrat}

Seks atau jenis kelamin adalah hal paling sering dikaitkan dengan Gender dan kodrat. Dikarenakan adanya perbedaan jenis kelamin, perempuan dan laki-laki secara kodrat berbeda satu sama lain Hubungan antara jenis kelamin (seks) dengan kodrat, secara sederhana dapat kita ilustrasikan seperti ini:

Ketika dilahirkan, laki-laki ataupun perempuan secara biologis memang berbeda. Laki-laki memiliki penis dan buah zakar sedangkan perempuan memiliki vagina. Pada saat mulai tumbuh besar, perempuan mulai terlihat memiliki payudara, mengalami haid dan memproduksi sel telur. Sementara laki-laki mulai terlihat memiliki jakun dan memproduksi sperma. Secara alamiah, perbedaan-perbedaan tersebut bersifat tetap, tidak berubah dari waktu ke waktu dan tidak dapat dipertukarkan fungsinya satu sama lain. Hal-hal seperti ini yang kemudian kita sebut dengan kodrat.

Berdasarkan hal tersebut, logikanya seseorang dapat dikatakan 'melanggar kodrat' jika mencoba melawan atau mengubah fungsi-fungsi biologis yang ada pada dirinya.

Gender sama sekali berbeda dengan pengertian jenis kelamin. Gender bukan jenis kelamin. Gender bukanlah perempuan ataupun laki-laki. Gender hanya memuat perbedaan fungsi dan peran sosial laki-laki dan perempuan, yang terbentuk oleh lingkungan tempat kita berada.

Gender tercipta melalui proses sosial budaya yang panjang dalam suatu lingkup masyarakat tertentu, sehingga dapat berbeda dari satu tempat ke tempat lainnya. Misalnya, laki-laki yang memakai tato di badan dianggap hebat oleh masyarakat dayak, tetapi di lingkungan komunitas lain seperti Yahudi misalnya, hal tersebut merupakan hal yang tidak dapat diterima.

Gender juga berubah dari waktu ke waktu sehingga bisa berlainan dari satu generasi ke generasi berikutnya. Contohnya, di masa lalu perempuan 
yang memakai celana panjang dianggap tidak pantas sedangkan saat ini dianggap hal yang baik untuk perempuan aktif.

Pertanyaannya sekarang, apakah Gender melanggar kodrat? Jawaban dari pertanyaan tersebut bisa kita analisa dari rangkaian pertanyaan berikut:

1. Apakah Gender berkaitan dengan ciri-ciri biologis manusia?

2. Apakah Gender bersifat tetap dari waktu ke waktu?

3. Apakah fungsi Gender tidak boleh berbeda dari satu tempat dengan tempat lainnya?

4. Apakah fungsi Gender tidak bisa dipertukarkan?

Jika jawaban dari semua pertanyaan tersebut adalah TIDAK, maka jelas bahwa Gender tidak melawan kodrat. Peran Gender tidak akan mengubah kodrat manusia, tidak mengubah jenis kelamin, tidak mengubah fungsi-fungsi biologis dalam diri perempuan menjadi laki-laki dan tidak juga dimaksudkan untuk mendorong perempuan mengubah dirinya menjadi seorang laki-laki, ataupun sebaliknya.

\subsection{Gender Tidak Melawan Kodrat}

Mengapa selama ini orang sering mencampuradukkan pengertian Gender dan kodrat? Dikarenakan perbedaan kodrat yang dimiliki perempuan dan laki-laki tersebut, masyarakat mulai memilah-milah peran sosial seperti apa yang (dianggap) pantas untuk laki-laki dan bagian mana yang (dianggap) sesuai untuk perempuan. Misalnya, hanya karena kodratnya perempuan mempunyai rahim dan bisa melahirkan anak, maka kemudian berkembang anggapan umum di masyarakat bahwa perempuanlah yang bertanggung jawab mengurus anak. Selanjutnya, anggapan tersebut semakin berkembang jauh dimana perempuan dipandang tidak pantas sibuk di luar rumah karena tugas perempuan mengurus anak akan terbengkalai. Kebiasaan ini lama kelamaan berkembang di masyarakat menjadi suatu tradisi dimana perempuan dianalogikan dengan pekerjaanpekerjaan domestik dan 'feminin' sementara laki-laki dengan pekerjaanpekerjaan publik dan 'maskulin'. 
Peran Gender adalah peran yang diciptakan masyarakat bagi lelaki dan perempuan. Peran Gender terbentuk melalui berbagai sistem nilai termasuk nilai-nilai adat, pendidikan, agama, politik, ekonomi, dan lain sebagainya. Sebagai hasil bentukan sosial, tentunya peran Gender bisa berubah-ubah dalam waktu, kondisi dan tempat yang berbeda sehingga sangat mungkin dipertukarkan diantara laki-laki dan perempuan. Mengurus anak, mencari nafkah, mengerjakan pekerjaan rumah tangga (memasak, mencuci, dll) adalah peran yang bisa dilakukan oleh laki-laki maupun perempuan, sehingga bisa bertukar tempat tanpa menyalahi kodrat. Dengan demikian, pekerjaan-pekerjaan tersebut bisa kita istilahkan sebagai peran Gender.

Jika peran Gender dianggap sebagai sesuatu yang dinamis dan bisa disesuaikan dengan kondisi yang dialami seseorang, maka tidak ada alasan lagi bagi kita untuk menganggap aneh seorang suami yang pekerjaan sehari-harinya memasak dan mengasuh anak-anaknya, sementara istrinya bekerja di luar rumah. Karena di lain waktu dan kondisi, ketika sang suami memilih bekerja di luar rumah dan istrinya memilih untuk melakukan tugas-tugas rumah tangga, juga bukan hal yang dianggap aneh.

Dalam masyarakat tradisional-patriarkhi (yaitu masyarakat yang selalu memposisikan laki-laki lebih tinggi kedudukan dan perannya dari perempuan) kita dapat melihat dengan jelas adanya pemisahan yang tajam bukan hanya pada peran Gender tetapi juga pada sifat Gender. Misalnya, laki-laki dituntut untuk bersifat pemberani dan gagah perkasa sedangkan perempuan harus bersifat lemah lembut dan penurut. Padahal, laki-laki maupun perempuan adalah manusia biasa, yang mempunyai sifat-sifat tertentu yang dibawanya sejak lahir. Sifat lemah lembut, perasa, pemberani, penakut, tegas, pemalu dan lain sebagainya, bisa ada pada diri siapapun, tidak peduli apakah dia perempuan atau laki-laki. Sayangnya, konstruksi sosial di masyarakat merubah pandangan 'netral' pada sifatsifat Gender tersebut.

Sejak kecil, anak laki-laki sudah dipaksa untuk 'tidak manusiawi' dimana mereka dilarang untuk menangis, bersikap lemah lembut dan pemalu. 
Ciri dan nilai-nilai seperti itu lama kelamaan berkembang di masyarakat menjadi norma yang dikuatkan, disosialisasikan, dan dipertahankan, bahkan terkadang dipaksakan sehingga dianggap kemudian sebagai tradisi. Konsep subyektif tersebut lama-kelamaan berkembang dalam berbagai alur kehidupan sosial masyarakat yang mengakibatkan adanya ketimpangan antara peran dan kedudukan perempuan dengan laki-laki. Ketimpangan peran Gender seperti ini membatasi kreativitas, kesempatan dan ruang gerak kedua belah pihak, baik itu laki-laki maupun perempuan. Contohnya, perempuan yang mempunyai kemampuan dalam bidang otomotif tidak bisa bebas menggunakan keahliannya untuk mendapatkan pekerjaan sebagai supir truk atau montir, karena dianggap bukan pekerjaan perempuan. Demikian pula halnya dengan laki-laki yang terampil menghias diri tidak mau menjadi perias pengantin karena dianggap bukan jenis pekerjaan laki-laki.

Seorang suami malu untuk bekerja di sektor domestik karena takut dianggap bukan laki-laki sejati. Padahal, suami yang memasak dan mengasuh anak tidak akan berubah fungsi biologisnya menjadi perempuan, demikian pula sebaliknya, perempuan yang mencari nafkah menjadi supir tidak akan berubah menjadi seorang laki-laki di keesokan harinya. Jadi jelas bahwa, bertukar peran sosial antar lakilaki dan perempuan sama sekali tidak menyalahi atau melawan kodrat. Berbagi dan bertukar peran Gender dalam kehidupan sehari-hari secara harmonis dapat membangun masyarakat yang lebih terbuka dan maju, karena semua orang mempunyai kesempatan, peluang dan penghargaan yang sama saat mereka memilih pekerjaan yang diinginkannya. Laki-laki maupun perempuan tidak dibatasi ruang geraknya untuk memanfaatkan kemampuannya semaksimal mungkin di bidang pekerjaan yang sesuai dengan minat dan keahliannya Dengan demikian, peran Gender yang seimbang memicu semakin banyak sumberdaya manusia produktif di masyarakat, yang dapat menyumbangkan kemampuannya untuk kemajuan bersama. 


\section{BAB 2 \\ Bagaimana Peran Gender Berlaku di Masyarakat?}

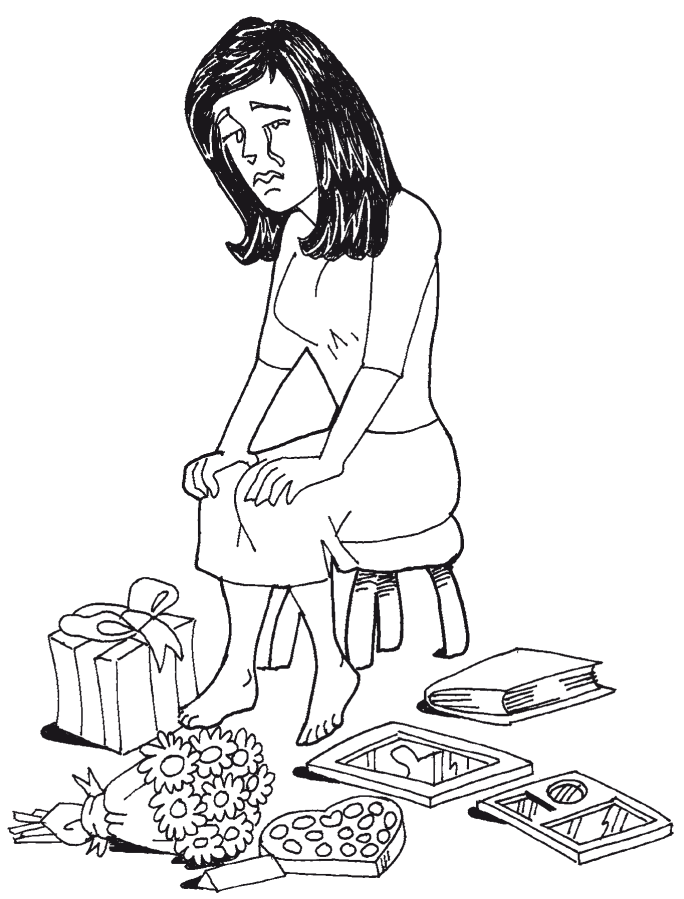

Gambar 2. Karena perempuan, saya boleh menangis kalau sedih ...?????? 


\subsection{Kesetaraan Gender}

Tidak sedikit orang yang masih berpikir bahwa membicarakan kesetaraan Gender adalah sesuatu yang mengada-ada. Hal yang terlalu dibesar-besarkan. Kelompok orang yang berpikir konservatif seperti ini menganggap bahwa kedudukan perempuan dan laki-laki dalam keluarga maupun dalam masyarakat memang harus berbeda.

'Perempuan tidak perlu sekolah tinggi-tinggi, percuma menghabiskan biaya saja, toh nantinya akan kembali juga masuk dapur'

Pernah mendengar ungkapan seperti itu? Hal ini masih kerap terlontar saat dipertanyakan apakah anak perempuan atau laki-laki yang akan diberikan kesempatan untuk meneruskan sekolah. Dari ungkapan tersebut sudah dapat kita lihat ada dua hal yang mencerminkan tidak adanya kesetaraan Gender yaitu:

- Perempuan tidak diberikan kesempatan yang sama dengan laki-laki untuk mendapatkan ilmu pengetahuan yang berguna bagi dirinya dan lingkungannya

- Laki-laki tidak diberikan penghargaan yang sama dengan perempuan jika mereka memilih 'masuk dapur'.

Pemikiran seperti ini umumnya muncul terutama pada kelompok masyarakat tradisional-patriarkhi yang masih menganggap bahwa sudah kodratnya perempuan untuk melakukan pekerjaan di dapur.

Sebagaimana yang telah dibahas di bagian muka buku ini, sekali lagi saya tegaskan bahwa peran Gender tidak sama dengan kodrat. Bukan kodratnya perempuan untuk masuk dapur, karena kegiatan memasak di dapur tidak ada kaitannya dengan ciri-ciri biologis yang ada pada perempuan. Kegiatan memasak di dapur (atau kegiatan domestik lainnya) adalah suatu bentuk pilihan pekerjaan dari sekian banyak jenis pekerjaan yang tersedia (misalnya guru, dokter, pilot, supir, montir, pedagang, dll), yang tentu saja boleh dipilih oleh perempuan ataupun laki-laki. Kesetaraan Gender memberikan pilihan, peluang dan kesempatan tersebut sama besarnya pada perempuan dan laki-laki. 
Supaya lebih jelas bagaimana kita bisa melihat kesetaraan Gender terjadi dalam lingkup kegiatan sehari-hari, berikut ilustrasi sederhana yang terjadi pada dua keluarga:

Yang pertama adalah seorang istri yang memilih bekerja di rumah dan suaminya memilih bekerja buruh di pabrik. Pada saat mengambil keputusan di keluarga, istri bebas menentukan apakah dia ingin bekerja di luar atau di dalam rumah. Demikian juga sang suami tidak keberatan untuk bertukar peran suatu saat istrinya mempunyai kesempatan bekerja di pabrik. Dalam hal ini kita bisa mengatakan bahwa telah tercipta kesetaraan Gender di dalam keluarga tersebut. Istri tidak dipaksa suami untuk tinggal di rumah dan suami tidak diharuskan bekerja di pabrik. Mereka memilih peran tersebut atas dasar kemampuan dan keinginan masing-masing pihak, tidak ada paksaan ataupun tekanan dari istri maupun suami. Kesetaraan Gender tercipta manakala istri dan suami mempunyai peluang yang sama untuk memilih jenis pekerjaan yang disukainya dan mempunyai posisi yang sama saat mengambil keputusan dalam keluarga.

Yang kedua, adalah seorang perempuan yang bekerja sebagai pengacara. Orang menganggap dia sudah sadar Gender, berpikiran modern dan sudah menikmati kesetaraan Gender dalam keluarganya. Penampilannya yang tegas dan gaya bicaranya lantang di depan publik, seolah-olah telah menghapus bayangan stereotype perempuan tradisional. Padahal yang terjadi sebenarnya adalah dia tidak memilih pekerjaan menjadi pengacara, melainkan terpaksa menjadi pengacara karena suaminya seorang pengusaha yang menginginkan sang istri menangani urusan-urusan hukum dengan klien-klien bisnisnya. Sang istri selalu bekerja dibawah tekanan suami, tidak mempunyai kebebasan mengeluarkan pendapatnya dan tidak mempunyai kesempatan untuk memilih pekerjaan lain yang diinginkannya.

Kita seringkali membuat dan menilai sesuatu hanya dari penampakan luarnya saja. Demikian pula halnya dengan kesetaraan Gender. Orang sering menghubung-hubungkan kesetaraan Gender dengan jenis pekerjaan yang dilakukan oleh perempuan. Namun, melihat contoh 
kedua keluarga di atas, jelas bagi kita bahwa jenis pekerjaan seseorang ataupun tempat bekerja yang dipilih oleh seseorang bukanlah ukuran yang dapat menunjukkan adanya kesetaraan Gender. Kesetaraan Gender ditunjukkan dengan adanya kedudukan yang setara antara laki-laki dan perempuan di dalam pengambilan keputusan dan di dalam memperoleh manfaat dari peluang-peluang yang ada di sekitarnya. Kesetaraan Gender memberikan penghargaan dan kesempatan yang sama pada perempuan dan laki-laki dalam menentukan keinginannya dan menggunakan kemampuannya secara maksimal di berbagai bidang. Tidak peduli apakah dia seorang ibu rumah tangga, presiden, buruh pabrik, supir, pengacara, guru ataupun profesi lainnya, jika kondisi-kondisi tersebut tidak terjadi pada dirinya maka dia tidak dapat dikatakan telah menikmati adanya kesetaraan Gender.

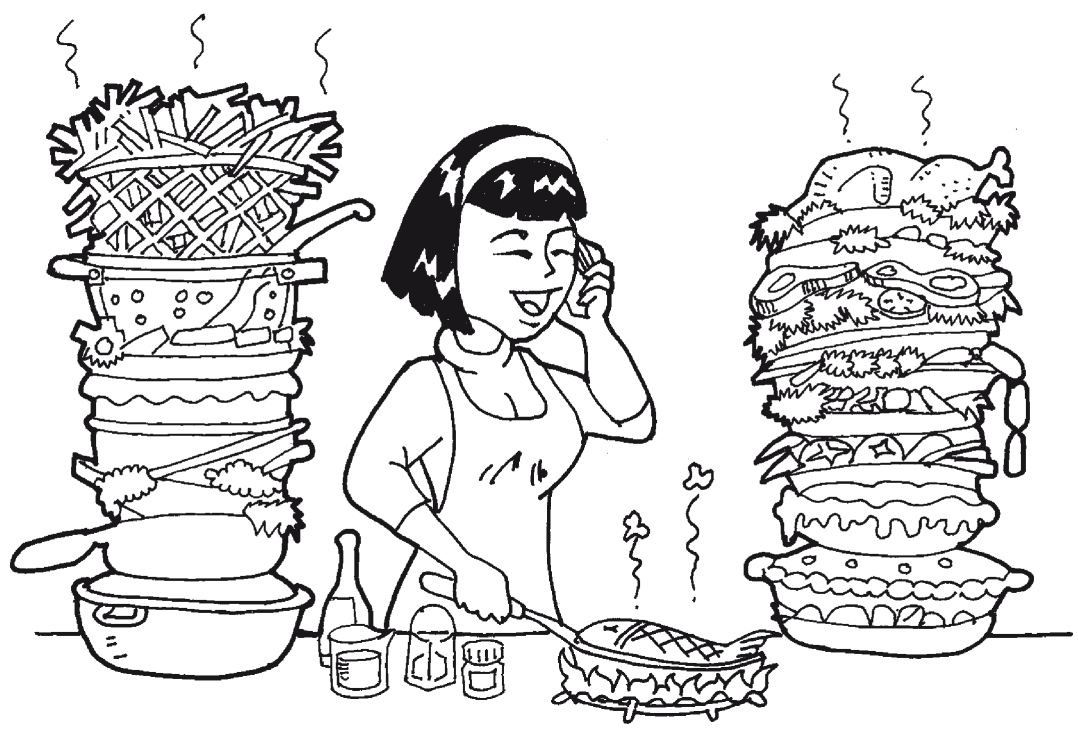

Gambar 3. Perempuan yang memilih untuk bekerja di dalam rumah tidak (selalu) berarti bahwa telah terjadi ketimpangan peran Gender di dalam rumah tangganya.... 
Di lain pihak, berkembangnya isu Gender di masyarakat dan maraknya inisiatif-inisiatif yang memperjuangkan kesetaraan Gender juga memicu sebagian orang menjadi berpikir dikotomis. Yang dimaksud adalah cara berpikir yang menempatkan perempuan dan laki-laki pada dua kubu yang berseberangan. Perempuan ditempatkan pada kubu yang teraniaya dan lemah, sedangkan laki-laki dipandang sebagai kubu penguasa yang menjajah perempuan. Hasil dari pemikiran seperti ini tidak akan memunculkan perilaku sadar Gender dan tidak akan mendukung ke arah terjadinya kesetaraan Gender. Yang akan muncul justru 'perang' antara perempuan pada kubu 'teraniaya' yang merasa terjajah, ingin memberontak dan menguasai laki-laki, sementara kaum laki-laki pada kubu 'penguasa' yang takut kekuasaannya diambil dan selalu khawatir terhadap dominasi kaum perempuan. Yang terjadi selanjutnya adalah terjadinya pertarungan antara kubu perempuan dan laki-laki tanpa jelas apa yang sebenarnya diperdebatkan. Kondisi seperti ini tentunya tidak mendukung sama sekali pada tujuan utama kita membicarakan 'kesetaraan Gender'.

Terminologi 'kesetaraan Gender' seringkali disalahartikan dengan mengambil alih pekerjaan dan tanggung jawab laki-laki.

'Katanya mau disamakan dengan laki-laki, kalau begitu panjat atap dan betulkan genting yang bocor, saya tidak perlu melakukan pekerjaan itu lagi sekarang'...

Bukan hanya sekali atau dua kali ungkapan seperti itu muncul dalam forum diskusi mengenai Gender. Kondisi seperti ini menyiratkan adanya kesimpangsiuran dalam memaknai kesetaraan Gender. Kesetaraan Gender bukan berarti memindahkan semua pekerjaan laki-laki ke pundak perempuan, bukan pula mengambil alih tugas dan kewajiban seorang suami oleh istrinya. Jika hal ini yang terjadi, bukan 'kesetaraan' yang tercipta melainkan penambahan beban dan penderitaan pada perempuan. Inti dari kesetaraan Gender adalah menganggap semua orang pada kedudukan yang sama dan sejajar (equality), baik itu laki-laki maupun perempuan. Dengan mempunyai kedudukan yang sama, maka setiap individu mempunyai hak-hak yang sama, menghargai fungsi dan 
tugas masing-masing, sehingga tidak ada salah satu pihak yang mereka berkuasa, merasa lebih baik atau lebih tinggi kedudukannya dari pihak lainnya.

Singkatnya, inti dari kesetaraan Gender adalah kebebasan memilih peluang-peluang yang diinginkan tanpa ada tekanan dari pihak lain, kedudukan dan kesempatan yang sama di dalam pengambilan keputusan dan di dalam memperoleh manfaat dari lingkungan. Bukankah keseimbangan selalu menciptakan kehidupan manusia menjadi lebih baik?

\subsection{Ketidakadilan Gender}

Sangat penting untuk perempuan mengetahui bentuk-bentuk ketidakadilan Gender sebab akan sulit untuk menentukan persamaan dan keseimbangan tanpa mengenali ketidakadilan Gender yang terjadi di sekitar kita. Kondisi seperti apa yang dapat dikatakan tidak adil Gender?

Ketidakadilan Gender terjadi manakala seseorang diperlakukan berbeda (tidak adil) berdasarkan alasan Gender. Misalnya, seorang perempuan yang ditolak kerja sebagai supir bis karena supir dianggap bukan pekerjaan untuk perempuan, atau seorang laki-laki yang tidak bisa menjadi guru TK karena dianggap tidak bisa berlemah lembut dan tidak bisa mengurus anak-anak kecil. Ketidakadilan Gender bisa terjadi pada perempuan maupun laki-laki. Namun pada kebanyakan kasus, ketidakadilan Gender lebih banyak terjadi pada perempuan. Itulah juga sebabnya masalahmasalah yang berkaitan dengan Gender sering diidentikkan dengan masalah kaum perempuan.

Secara garis besar bentuk-bentuk ketidakadilan Gender yang sering terjadi (terutama pada perempuan) adalah sebagai berikut:

\subsubsection{Penomorduaan (Subordinasi)}

Penomorduaan atau subordinasi pada dasarnya adalah pembedaan perlakuan terhadap salah satu identitas sosial, dalam hal ini adalah 
terhadap perempuan. Cukup adil rasanya kalau saya menganggap bahwa dalam kultur budaya kita di Indonesia, perempuan masih dinomorduakan dalam banyak hal, terutama dalam pengambilan keputusan. Suara perempuan dianggap kurang penting dalam proses pengambilan keputusan, terutama yang menyangkut kepentingan umum. Akibatnya, perempuan tidak dapat mengontrol apabila keputusan itu merugikan mereka dan tidak bisa ikut terlibat maksimal saat hasil keputusan tersebut diimplementasikan. Tradisi, adat, atau bahkan aturan agama paling sering digunakan sebagai alasan untuk menomorduakan perempuan. Padahal secara teologis (dipandang dari sudut keagamaan), prinsip-prinsip tauhid (ketuhanan, berlaku untuk agama apapun) pada dasarnya adalah menganggap semua mahluk yang ada di dunia ini sama kedudukannya di mata Tuhan. Implikasinya, jika Penciptanya saja sudah menganggap kedudukan semua manusia adalah sama, laki-laki ataupun perempuan, kulit hitam atau putih, dan lain sebagainya, alasan apa yang membolehkan adanya perempuan diperlakukan berbeda dari laki-laki? Oleh karena itu menganggap kedudukan laki-laki lebih tinggi dan lebih penting dari perempuan dikarenakan motif keagamaan, menurut saya, kurang beralasan.

Manusia dilahirkan sama, tanpa baju pangkat, status ataupun jabatan. Lingkungan (masyarakat) yang kemudian memperkenalkan dan menetapkan nilai dan norma tertentu yang menyebabkan terjadinya pembedaan-pembedaan perlakuan. Jika masyarakat dulu bisa membangun norma, nilai dan tradisi yang kemudian kita jalani sekarang, bukankah hal yang sama bisa kita lakukan juga saat ini? Bukankah kita sekarang juga bagian dari masyarakat yang mempunyai hak untuk mengubah, menetapkan dan mengembalikan nilai-nilai tersebut sehingga tidak terjadi ketidakadilan Gender yang serupa di masa datang? Perlu diingat bahwa Gender bisa berubah dari waktu ke waktu dan manusia (masyarakat) bisa mengubah kondisi ketidakadilan Gender tersebut menjadi keseimbangan atau kesetaraan.

Kita ambil contoh lain dalam bidang pendidikan. Perempuan masih sering dinomorduakan, terutama pada lingkup keluarga di pedesaan atau di kalangan masyarakat yang lemah dalam status ekonominya. 
Dengan tingginya biaya pendidikan dan terbatasnya dana yang tersedia, anak perempuan seringkali mendapat tempat kedua setelah anak lakilaki, dalam hal melanjutkan pendidikan tinggi. Dengan anggapan bahwa laki-laki akan menjadi penopang keluarga, pencari nafkah utama maka dia harus mempunyai tingkat pendidikan lebih tinggi dari perempuan. Anggapan seperti ini bukan saja hanya merugikan perempuan, tetapi juga memberikan tekanan dan tuntutan yang luar biasa berat pada laki-laki. Laki-laki dituntut harus kuat, harus pandai, harus mempunyai pekerjaan yang bagus dan sederet kata 'harus' lainnya, sebagai 'konsekuensi' dari pandangan masyarakat yang menempatkan mereka pada kedudukan lebih tinggi daripada perempuan.

Sementara itu, perempuan yang dianggap nomor dua dan tidak begitu penting dalam peran sosialnya di masyarakat, perlahan-lahan akan semakin tertinggal dan tidak bisa berkontribusi banyak terhadap prosesproses pembangunan yang berkembang di lingkungannya. Tidak heran, jika sampai saat sekarang ini, pembangunan di negara kita masih jauh tertinggal dibandingkan negara-negara maju lainnya yang relatif lebih sedikit memiliki sumberdaya. Salah satu sebabnya adalah sumberdaya manusia yang produktif dan dapat menyumbangkan kemampuannya untuk kemajuan negara, masih sangat terbatas jumlahnya.

Hasil survei BPS tahun 2000 diketahui bahwa jumlah perempuan di Indonesia hampir setengahnya $(49,9 \%)$ dari jumlah penduduk lakilaki (50,1\%). Dari jumlah tersebut, pada tahun $2001^{1}$ terdapat $14,54 \%$ perempuan yang buta huruf (dibandingkan laki-laki 6,87\%) dan sebesar 12,28\% pada tahun 2003 (dibandingkan dengan laki-laki 5,48\%). Padahal pada saat yang sama, di negara-negara maju, jumlah perempuan yang mengenyam pendidikan tinggi (setingkat universitas) lebih tinggi dibandingkan dengan laki-laki. Sebagai contoh, di New Zealand tercatat $89 \%$ pelajar perempuan melanjutkan pendidikan ke tingkat universitas dibandingkan pelajar laki-laki yang hanya mencapai 62\%; di Iceland terdapat $80 \%$ pelajar perempuan yang memutuskan ingin masuk ke tingkat lebih tinggi dibandingkan pelajar laki-laki yang hanya mencapai 42\%; dan di Inggris dilaporkan bahwa $49 \%$ perempuan mengenyam pendidikan universitas dibandingkan laki-laki yang hanya mencapai $41 \%$ nya $^{2}$. 
Bisa kita bayangkan seberapa besar sumberdaya manusia (perempuan) yang potensial untuk membangun negara ini telah disia-siakan dengan sistem budaya tradisional-patriarkhi. Sumberdaya manusia yang berpendidikan rendah cenderung mempunyai peluang lebih sempit untuk dapat memanfaatkan kemampuannya secara maksimal di bidang pekerjaan yang diminatinya. Jika saja semua orang, baik laki-laki maupun perempuan diberikan peluang yang sama untuk maju, untuk lebih produktif menyumbangkan kemampuannya di berbagai sektor yang berbeda, dengan dukungan sumberdaya alam yang kaya seperti ini bukan tidak mungkin kita seharusnya sudah menjadi salah satu negara adidaya. Sayangnya, sampai saat ini masih terlalu banyak belenggu-belenggu yang menghambat proses perubahan ke arah kemajuan tersebut. Budaya, agama, suku, tradisi dan label-label lain seringkali dijadikan tameng alasan untuk menghambat perempuan yang ingin mengembangkan diri menjadi sosok manusia yang lebih bermanfaat.

\subsubsection{Pelabelan Negatif pada Perempuan (Stereotype)}

"isi kepala perempuan itu: satu pikiran dan sembilan sisanya hanya emosi saja"

Pertama kali mendengar kalimat seperti itu, saya sangat kecewa. Bukan karena tidak tahu bahwa perempuan sering dianggap lebih emosional dibandingkan dengan laki-laki, tetapi tidak menyangka bahwa begitu kentalnya pelabelan negatif yang dilekatkan pada diri perempuan. Pada saat perempuan berusaha menyampaikan ketidaksetujuannya akan sesuatu hal dengan mengemukakan alasan-alasan, dianggap bahwa dia terlalu cerewet, emosional dan tidak berpikir rasional. Sedangkan jika laki-laki berada pada kondisi yang sama, mungkin dianggap tegas dan berwibawa karena mempertahankan pendapatnya.

Label negatif senada banyak kita temukan di masyarakat. Contohnya, jika perempuan pulang larut malam dari tempatnya bekerja dipandang sebagai perempuan tidak benar, sedangkan jika laki-laki dianggap pekerja keras. Padahal mungkin mereka mempunyai jenis pekerjaan dan kesibukan yang sama. Citra buruk perempuan yang emosional, tidak rasional, lemah, cerewet, pendendam, penggoda dan lain sebagainya, 
secara tidak langsung telah menghakimi dan menempatkan perempuan pada posisi yang tidak berdaya di masyarakat. Dalam pepatah Jawa bahkan disebutkan bahwa perempuan itu kanca wingking (berperan di belakang) yang swarga nunut neraka katut (ke surga ikut ke neraka juga menurut saja). Dengan label-label negatif seperti itu, mustahil bagi perempuan untuk dapat memperoleh kedudukan yang sejajar dengan laki-laki dalam pandangan masyarakat. Perempuan selalu akan tertinggal di belakang karena dianggap memang posisi terbaiknya ada di belakang laki-laki.

Sayangnya, label-label negatif seperti ini justru semakin ditumbuhkembangkan oleh program-program yang menamakan dirinya 'Program Pemberdayaan Masyarakat'. Kita ambil salah satu contoh, misalnya program PKK yang lebih sering menyelenggarakan kegiatan yang berhubungan dengan rumah tangga seperti: membuat kue, kerajinan tangan, mengurus bayi, dan lain sebagainya. Kegiatan-kegiatan yang dilakukan harus mengacu pada 10 Program PKK yang menitikberatkan kegiatan-kegiatannya pada hal-hal domestik seperti tercermin dalam butir ke 5, yaitu Perumahan dan Tata Laksana Rumah Tangga. Hal ini semakin memperkuat anggapan bahwa tempat perempuan adalah di rumah, jadi tugas dan kewajiban perempuanlah untuk merawat rumah dan keluarga. Selain itu, ketua PKK tidak dipilih secara demokratis, melainkan karena 'label' jabatan atau pekerjaan suami. Jika suaminya camat, maka otomatis istri camat adalah ketua PKK kecamatan. Padahal bukan tidak mungkin istri camat tidak tertarik untuk menjadi ketua PKK atau mungkin ada anggota lain yang lebih mampu menjadi ketua tetapi tidak bisa berada pada posisi tersebut karena suaminya bukan camat. Sistem seperti ini semakin memperkuat pandangan di masyarakat bahwa peran sosial perempuan ditentukan oleh laki-laki (suami), bukan oleh kemampuan dan keahlian yang ada pada dirinya.

Saya tidak mengatakan bahwa program-program kegiatan PKK buruk atau tidak berguna. Sepuluh program kerja PKK yang dikembangkan oleh Ny. Kardinah Soepardjo Roestam ini telah diuji dan dilaksanakan lebih dari 30 tahun di Indonesia dan telah membantu banyak kalangan perempuan untuk mendapatkan informasi-informasi yang bermanfaat. Namun kita juga tidak bisa memungkiri kenyataan dalam banyak 
hal, dimana program-program PKK tersebut mendorong perempuan untuk lebih terpuruk dalam fungsi tradisionalnya sebagai seorang 'ibu' dan seorang 'istri' ${ }^{3}$ yang bertugas menjaga keutuhan dan kesejahteraan keluarga. Untuk itu perlu dipertimbangkan untuk melakukan perubahanperubahan dalam program kerja PPK ke arah 'Pemberdayaan Perempuan'. Artinya program yang mendorong peningkatan kapasitas perempuan, menggali potensi dan membangun kepercayaan diri perempuan bahwa dia melakukan sesuatu karena dia ingin dan mampu melakukannya, bukan karena harus melakukannya disebabkan status, jabatan atau pekerjaan suaminya. Menjadikan perempuan lebih berdaya (mampu), bukan diperdayai. Perencanaan program kegiatan PKK pada dasarnya dapat dibuat lebih bervariasi, lebih informatif dan mengupas topik-topik strategis (misalnya tentang hak asasi, politik, hukum, ekonomi, dsb) sehingga perempuan mempunyai wawasan yang lebih luas daripada halhal yang menyangkut kegiatan-kegiatan praktis untuk lingkup domestik (kerumahtanggaan). Dengan demikian PKK juga dapat menjadi sarana bertukar informasi dan penyaluran aspirasi perempuan untuk ikut terlibat aktif dan diakui perannya dalam proses-proses pembangunan yang ada di lingkungan sekitarnya.

\subsubsection{Peminggiran (Marginalisasi)}

Sebagai akibat langsung dari penomorduaan (subordinasi) posisi perempuan serta melekatnya label-label buruk pada diri perempuan (stereotype), perempuan tidak memiliki peluang, akses dan kontrol -seperti laki-laki- dalam penguasaan sumber-sumber ekonomi. Dalam banyak hal, lemahnya posisi seseorang dalam bidang ekonomi mendorong pada lemahnya posisi mereka dalam pengambilan keputusan. Lebih jauh hal ini akan berakibat pada terpinggirkan atau termarginalkannya kebutuhan dan kepentingan pihak-pihak yang lemah tersebut, dalam hal ini adalah perempuan.

Di kantor-kantor, staf perempuan sulit mendapatkan posisi pengambil keputusan. Perempuan dianggap masih tidak mampu untuk melakukan tugas-tugas penting dan serius seperti menangani proyek-proyek pembangunan. Sebagai contoh di Kabupaten Tanjabbar, perempuan yang bekerja sebagai pegawai negeri sipil berjumlah kurang dari 10\%, 
yaitu 44 orang dari total 510 orang. Dari jumlah tersebut hanya 6 orang perempuan yang menempati posisi eselon III dan tidak ada satupun staf perempuan yang menempati posisi pengambil keputusan yaitu eselon IIa dan IIb (misalnya kepala dinas atau badan $)^{4}$.

Perempuan juga belum berpartisipasi aktif dalam perencanaan programprogram pembangunan di daerah. Contohnya, dalam proses penataan tata ruang daerah dan kehutanan di Kab. Tanjabbar. Hampir seluruh anggota aktif dari Tim 9, yakni sebuah tim yang bertugas menyelesaikan berbagai permasalahan tata ruang kabupaten, adalah staf laki-laki yang berasal dari badan atau instansi-instansi terkait di kabupaten. Hanya satu (1) orang staf perempuan yang terlibat dalam proses dan itupun tidak terlibat aktif dalam pengambilan keputusan karena tidak selalu dapat hadir di setiap pertemuan tim.

Fenomena seperti ini umum terjadi dalam tubuh instansi pemerintahan, baik skala nasional maupun daerah. Staf perempuan yang terlibat dalam struktur kepengurusan atau pengelolaan sebuah proyek, mereka cenderung sulit mendapatkan posisi pengambil keputusan proyek. Kebanyakan, staf perempuan lebih berfungsi sebagai 'peran pembantu', misalnya untuk mencatat hasil rapat, mengetik laporan, dan peran lainnya yang tidak memungkinkan mereka untuk mempunyai akses dan kontrol langsung terhadap proses pengambilan keputusan.

Kondisi ini terjadi pula dalam tubuh lembaga legislatif di kabupaten tersebut. Walaupun ada ketentuan kuota 30\% untuk keterwakilan perempuan di lembaga legislatif5, hasil Pemilu 2004 di Tanjabbar menunjukkan hanya dua (2) dari 30 orang anggota DPRD yang berjenis kelamin perempuan. Jumlah ini berkurang dari sebelumnya dimana terdapat 3 orang perempuan yang duduk di DPRD. Ini merupakan sebuah ironi, karena pada periode sebelumnya, ketika belum ada aturan kuota 30\%, justru keterwakilan perempuan di tubuh DPRD kabupaten Tanjabbar lebih tinggi. Di Kab. Bungo, kondisinya tidak lebih baik dari Tanjabbar, dimana dari total 30 orang hanya satu orang perempuan yang duduk di lembaga legislatif. 
Pembedaan posisi dan kedudukan perempuan di tempat bekerja berakibat bukan hanya pada terbatasnya manfaat finansial yang diterima (gaji), namun juga perempuan tidak mempunyai akses dan kontrol terhadap program-program kerja yang direncanakan, apakah akan berimplikasi positif atau negatif terhadap perempuan, atau malah sama sekali mengesampingkan kepentingan dan kebutuhan perempuan (buta Gender). Sebagai contoh, jika diputuskan adanya perubahan dalam tata ruang kabupaten dimana sebagian lahan kosong akan dialihfungsikan menjadi perkebunan kelapa sawit skala besar. Padahal, lahan tersebut merupakan lahan penggembalaan dimana kaum perempuan dapat dengan mudah membawa ternak mereka ke tempat tersebut atau mengambil rumput untuk dibawa pulang. Namun, hal tersebut tidak menjadi pertimbangan di tingkat pengambilan keputusan karena mereka menganggap proyek pengembangan kepala sawit lebih penting dalam menambah PAD dan menyediakan lapangan kerja baru bagi orang sekitarnya, khususnya lakilaki. Mereka bisa mendapatkan kredit dan pekerjaan dari perusahaan kelapa sawit. Tujuan tersebut terlihat mulia tetapi ada kepentingan lain yang terpinggirkan dan terlupakan, yaitu kebutuhan perempuan di desa yang kehilangan sumber kehidupannya.

Dalam lingkup masyarakat tradisional seperti yang ada di banyak tempat di Indonesia, kondisi perempuan yang terpinggirkan dianggap lumrah dan biasa. Seperti sudah ada aturan tidak tertulis bahwa perempuan tidak aktif diikutkan dalam pertemuan-pertemuan penting di masyarakat (misalnya dalam kepengurusan lembaga adat atau musbang) karena laki-laki yang ditempatkan pada posisi pemegang kontrol dan pembuat keputusan. Lebih jauh lagi, perempuan yang berasal dari etnis minoritas (misalnya imigran pendatang) biasanya memiliki peluang partisipasi yang lebih sempit lagi karena mereka tidak diperhitungkan sebagai bagian dari adat asli yang menetapkan norma-norma yang berlaku di tempat mereka tinggal. Aturan-aturan tradisional seperti ini diperparah dengan perangkat hukum dan birokrasi negara kita yang tidak sensitif Gender. Contohnya, aturan kependudukan yang tidak mendukung perempuan menjadi kepala keluarga, aturan perbankan yang tidak bisa diakses oleh perempuan (perempuan bisa mendapat kredit hanya jika ada ijin tertulis dari suami), dan bahkan aturan-aturan di bidang pendidikan 
formal, seperti keharusan adanya ijin suami untuk pegawai negeri perempuan yang ingin sekolah ke luar negeri. Pembedaan perlakuan seperti ini semakin memarginalkan perempuan karena mereka tidak punya kekuasaan (power) dalam mengakses sumber-sumber ekonomi dan sumber-sumber informasi yang penting untuk meningkatkan kualitas penghidupan mereka.

Ketidakadilan Gender juga terjadi dalam lingkup kerja di pabrik-pabrik, di ladang, sawah, dan kalangan masyarakat umumnya. Pekerjaan perempuan dianggap lebih ringan sehingga mendapat gaji rendah dari laki-laki. Dari data yang dikumpulkan oleh organisasi pekerja dunia (ILO) pada tahun 2002 menyebutkan bahwa pekerja perempuan di kebanyakan negaranegara berkembang (termasuk Indonesia) mendapat bayaran lebih rendah dari laki-laki untuk jenis pekerjaan yang sama ${ }^{6}$. Situasi yang sama terjadi di daerah penelitian CAPRi yaitu di desa Sungai Telang (Tanjabbar) dan desa Lubuk Kambing (Bungo). Perempuan dibayar Rp. 20,000 - 25,000 sedangkan laki-laki dibayar Rp. 30,000 untuk jenis pekerjaan yang sama sebagai buruh harian. Perbedaan perlakuan seperti ini berlandaskan pada stereotype perempuan yang dianggap lebih lemah dari laki-laki, sehingga pekerjaan yang dilakukan dianggap lebih ringan dan sedikit. Padahal dalam kenyataannya, pekerjaan yang dilakukan buruh harian perempuan sama beratnya dengan laki-laki. Bahkan perempuan cenderung bekerja lebih keras dan lebih lama karena tidak memerlukan waktu istirahat yang banyak seperti untuk merokok atau minum kopi (sebagaimana kebiasaan petani laki-laki pada saat mereka bekerja sebagai buruh di ladang).

Dengan berlanjutnya ketidakadilan Gender seperti ini, posisi perempuan semakin lemah dari sisi ekonomi dan selanjutnya berakibat pada lemahnya posisi perempuan dalam pengambilan keputusan di dalam keluarga. Dalam kondisi yang demikian menjadi mustahil bagi perempuan untuk memperjuangkan kebutuhan dan kepentingannya serta untuk mendapatkan akses dan kontrol terhadap sumberdaya, seperti kepemilikan dan penggunaan lahan.

\subsubsection{Beban Kerja Berlebih (Multi-burdened)}

Ketidakadilan Gender yang terjadi pada perempuan bisa berbentuk 
muatan pekerjaan yang berlebihan. Hal inilah yang juga sering menjadi bahan diskusi dalam forum-forum yang membahas tentang Gender. Sebagian orang khawatir bahwa jika perempuan semakin pintar, semakin maju, ikut aktif dalam kegiatan-kegiatan sosial, meningkat kemampuan dan keahliannya di berbagai bidang, maka pada akhirnya 'kebebasan berekspresi' tersebut akan berbalik menjadi senjata makan tuan. Beban kerja perempuan menjadi semakin bertambah banyak dengan tambahan kegiatan-kegiatan yang ingin dia ikuti di luar rumah. Hal ini disebabkan karena pada saat yang bersamaan perempuan masih terbebani dengan setumpuk tugas dan pekerjaan di dalam rumah tangganya (domestik). Di Desa Lubuk Kambing misalnya, rata-rata perempuan mempunyai 20 jenis pekerjaan domestik yang dilakukannya sehari-hari sebagai pekerjaan rutin, tanpa bantuan laki-laki. Sebagian yang lain, terutama dari kaum laki-laki, khawatir jika perempuan dilibatkan secara aktif dalam kegiatan-kegiatan sosial, mereka tidak punya waktu dan tidak bersedia lagi melakukan pekerjaan-pekerjaan di rumah tangga.

'Jangan sampai ketika perempuan sadar Gender kemudian menjadi tidak mau membuatkan kopi untuk suaminya dan membuat situasi rumah tangga menjadi berantakan'.

Bukan hanya satu dua kali saya mendengar celotehan seperti itu diungkapkan kaum laki-laki. Pertanyaannya: Apakah hanya perempuan yang bisa membuat kopi? Apakah hanya perempuan yang harus menjaga situasi rumah tangga tetap harmonis? Apakah hanya tugas perempuan untuk membuat rumah tangga bahagia? Jika jawabannya tidak, maka tidak perlu takut bahwa perempuan yang sadar Gender akan membuat situasi di rumah tangga menjadi runyam. Terlebih lagi, bukan hanya perempuan yang harus sadar Gender, tetapi juga laki-laki sebagai bagian dari keluarga yang mempunyai hak dan kewajiban yang setara dalam keluarga. Keluarga yang sudah sadar Gender akan lebih menyadari bahwa kebahagiaan rumah tangga adalah tanggung jawab bersama dan Gender tidak dijadikan alasan bagi perempuan untuk berbuat semena-mena terhadap laki-laki ataupun sebaliknya.

Jadi jelas bahwa kekhawatiran-kekhawatiran tersebut sebenarnya tidak 
beralasan. Jika seluruh anggota keluarga, laki-laki maupun perempuan sudah sadar Gender maka beban tanggung jawab yang ada dalam keluarga tersebut akan terbagi rata dan tidak bertumpuk pada satu orang. Tidak pada istri, ibu, suami, anak dan anggota keluarga lainnya. Inti dari kesetaraan Gender seperti yang telah dibahas di muka, adalah saling menghargai hak-hak dan kewajiban masing-masing, saling membantu dan berbagi peran untuk meringankan beban pekerjaan satu sama lain, karena semua jenis pekerjaan yang dilakukan adalah sama pentingnya. Pekerjaan domestik tidak lebih rendah posisinya dari peran publik. Jika seluruh anggota keluarga aktif dalam kegiatan publik, maka mereka dapat mencari alternatif waktu dan cara bagaimana kedua peran tersebut bisa dilakukan bersama-sama, misalnya dengan mengatur waktu secara bergiliran. Dengan demikian, masing-masing mempunyai kesempatan yang sama untuk mencurahkan waktu, tenaga dan kemampuan yang dimilikinya secara maksimal ketika melakukan peran publik (mencari nafkah, berinteraksi sosial, dll) maupun peran domestik (rumah tangga), karena tidak terbebani dengan 'antrian' tugas-tugas lain yang harus dikerjakannya. Komunikasi dan keterbukaan tentunya menjadi kunci untuk terciptanya kesetaraan Gender dalam, sehingga tidak ada salah satu pihak yang 'terpaksa' harus mengalah untuk pihak lainnya.

\subsubsection{Kekerasan}

Kekerasan terhadap perempuan adalah salah satu bentuk ketidakadilan Gender yang mulai ramai dibicarakan akhir-akhir ini dalam media. Bentuk kekerasan yang terjadi sangat beragam, mulai dari kekerasan fisik (seperti pemukulan), kekerasan psikis (misalnya, kata-kata yang merendahkan atau melecehkan), kekerasan seksual (contohnya perkosaan), dll. Bentukbentuk kekerasan ini bisa terjadi pada siapa saja, dan dimana saja, bisa di wilayah pribadi (rumah tangga) atau di wilayah publik (lingkungan).

Sekitar tahun 60-an, dengan difasilitasi oleh kelompok-kelompok pergerakan perempuan ${ }^{8}$, kasus-kasus kekerasan terhadap perempuan yang dilakukan oleh pasangannya mulai muncul ke permukaan ${ }^{9}$. Sebelum itu, kekerasan dalam wilayah pribadi (rumah tangga) atau yang sekarang sering disebut dengan istilah KDRT (Kekerasan Dalam Rumah Tangga) adalah hal yang tabu untuk dibicarakan dan diketahui publik. Sebagian 
karena alasan takut dan sebagian lain karena malu oleh pandangan masyarakat. Hal ini lagi-lagi terjadi karena anggapan bahwa istri harus menjaga nama baik suami, dan kebahagiaan keluarga ditentukan oleh bagaimana istri menciptakan keharmonisan dalam rumah tangganya. Sehingga jika terjadi masalah dalam keluarga, sering perempuan yang disalahkan. Demikian juga jika terjadi perkosaan, sebagian perempuan tidak mau melaporkan tindak kekerasan seksual tersebut karena takut kecaman dan anggapan 'miring' dari masyarakat.

Pada kebanyakan kasus, korban KDRT adalah perempuan. Tentu saja laki-laki pun bisa jadi korban kekerasan dalam rumah tangga meskipun jumlahnya jauh lebih sedikit dibandingkan dengan jumlah korban kekerasan terhadap perempuan. Dari sekitar 10 sampai 69 persen dari pasangan hidup di dunia, perempuan menjadi korban kekerasan fisik dari pasangannya ${ }^{10}$. Prosentase ini belum termasuk pada kekerasan psikis (mental) dan seksual, yang tentunya menimbulkan dampak lebih panjang dan kompleks bukan hanya bagi korban kekerasan tersebut (perempuan) tapi juga bagi yang menyaksikan kekerasan tersebut terjadi di dalam keluarga, yaitu anak-anak.

\subsection{Sensitif Gender Diperlukan dalam Program-program Pembangunan Daerah}

Kebanyakan program-program pembangunan di daerah masih belum memasukkan komponen Gender sebagai faktor penting yang mengukur keberhasilan program. Tidak terkecuali program pembangunan yang berkaitan dengan penggunaan sumberdaya alam dan lingkungan seperti kehutanan, pertanian, pertambangan, $\mathrm{dsb}$ ataupun yang berhubungan dengan pemberdayaan masyarakat seperti pengembangan koperasi tani. Seringkali program-program tersebut dianggap telah berhasil melibatkan masyarakat jika memenuhi kriteria berikut ${ }^{11}$ :

- masyarakat lokal telah berpartisipasi aktif dalam proses pengambilan keputusan

- adanya pemerataan distribusi biaya dan manfaat 
- upaya-upaya pengelolaan sumberdaya yang berkelanjutan sudah dilakukan secara efisien

Dengan memenuhi ketiga komponen di atas, suatu program kegiatan yang melibatkan masyarakat memang akan terlihat sukses. Namun, jika kita melihatnya dari perspektif Gender, bukan tidak mungkin program tersebut jauh dari tanda-tanda keberhasilan. Mengapa demikian? Mari kita bahas satu-persatu bagaimana ketiga komponen di atas bisa berbeda hasilnya jika kita gabungkan dengan komponen Gender di dalam analisisnya.

Pertama, Tingkat partisipasi biasanya diukur dengan keterwakilan dan kontribusi pendapat/ide yang diperoleh pada saat berlangsungnya suatu program kegiatan. Dengan mengesampingkan komponen Gender, suatu kegiatan dapat dikatakan telah melibatkan komunitas lokal jika jumlah anggota masyarakat yang terlibat aktif dalam setiap kegiatan dianggap telah mewakili jumlah penduduk yang ada di daerah tersebut. Hal ini bisa terlihat dari banyaknya anggota masyarakat yang hadir di setiap pertemuan, dan keaktifan mereka dalam pelaksanaan kegiatan tersebut. Namun jika kita memasukkan komponen Gender, beberapa kriteria baru diperlukan untuk melihat sejauh mana tingkat partisipasi masyarakat lokal dalam program tersebut, yakni:

- Apakah perempuan mempunyai peluang yang sama besarnya dengan laki-laki untuk ikut terlibat dalam kegiatan tersebut

- Berapa persentase perempuan yang berpartisipasi dalam kegiatan tersebut

- Dari jumlah keseluruhan peserta program, berapa banyak perempuan yang duduk dalam kepengurusan program (misalnya panitia pelaksana, dll)

- Apakah perempuan yang duduk dalam kepengurusan mempunyai akses dan kontrol dalam perencanaan, pelaksanaan dan pengawasan program

- Bagaimana tingkat keaktifan perempuan peserta program dalam kegiatan yang dilakukan (peserta aktif atau cuma hadir sebagai peserta pasif) 
Dengan mengetahui informasi-informasi tersebut dapat diukur sejauh mana program kegiatan yang dilaksanakan telah melibatkan seluruh komponen 'masyarakat lokal' (termasuk perempuan) secara aktif dalam proses pengambilan keputusan. Kecenderungan yang sering terjadi adalah program-program kegiatan/pembangunan di daerah hanya menghitung jumlah masyarakat yang ikut serta dalam program tanpa melihat apakah ada perempuan yang terlibat ataukah hanya laki-laki yang dianggap telah mewakili suara satu keluarga, dengan label 'kepala keluarga'.

Kedua, Distribusi manfaat program dianggap sudah merata jika masyarakat yang terlibat program tersebut telah merasakan hasilnya. Kita ambil salah satu contoh program kehutanan, misalnya pemberian ijin pemungutan kayu rakyat. Program ini dikatakan berhasil mencapai 'sasaran program' yaitu memberikan manfaat hutan pada masyarakat lokal, manakala anggota masyarakat yang tergabung dalam koperasi atau kelompok yang mendapat ijin tersebut memperoleh pendapatan yang seimbang dan merata. Namun, jika kita menganalisanya dari sisi Gender, kondisi tersebut belum tentu mencerminkan keberhasilan dari sistem perijinan tersebut. Beberapa hal yang masih perlu dipenuhi supaya program tersebut menjadi lebih sensitif Gender antara lain:

- Apakah perempuan mempunyai akses yang sama untuk memperoleh ijin pemungutan kayu tersebut? (dilihat dari sisi prosedur dan prasyarat memperoleh ijin, peluang negosiasi, $\mathrm{dsb}$.)

- Berapa jumlah perempuan yang memperoleh manfaat dari sistem perijinan tersebut

- Apakah dampak yang ditimbulkan oleh sistem perijinan tersebut mempengaruhi perempuan (misalnya, perempuan kehilangan tempat mencari kayu bakar, sumber air, dsb)

Kriteria-kriteria tersebut dapat diperluas dengan melihat apakah perempuan juga mempunyai kontrol untuk memutuskan bagaimana manfaat yang diterimanya ingin dia gunakan. Karena pada kebanyakan kasus, selain tidak mempunyai akses terhadap sumber-sumber ekonomi, perempuan juga sangat lemah posisinya dalam menentukan kontrol terhadap penggunaan sumberdaya yang dimilikinya. 
Jika hal-hal tersebut di atas telah menunjukkan adanya keseimbangan antara jumlah perempuan dan laki-laki yang mendapatkan manfaat program, maka dapat kita katakan bahwa manfaat program tersebut telah terdistribusikan secara merata ditinjau dari perspektif Gender .

Ketiga, Efisiensi pelaksanaan program dapat dilihat dari bagaimana peserta program dapat menjaga ketersediaan dan keberlangsungan sumberdaya yang diperlukan untuk keberlanjutan program di masa mendatang. Kita ambil contoh misalnya kegiatan yang berhubungan dengan penggunaan lahan pertanian. Dengan memasukkan komponen Gender ke dalam analisis program, kita memerlukan beberapa informasi tambahan antara lain:

- Bagaimana posisi perempuan dalam kepemilikan lahan pertanian di daerah tersebut?

- Apakah perempuan mempunyai posisi yang sama dalam pengambilan keputusan atas penggunaan lahan tersebut? (misalnya penentuan jenis tanaman )

- Apakah perempuan mempunyai akses dan kontrol terhadap modal (capital) yang cukup untuk dapat mengelola lahan tersebut?

- Apakah perempuan mempunyai akses yang cukup terhadap informasi yang berkaitan dengan penggunaan lahan tersebut?

- Apakah teknik-teknik pengelolaan lahan yang ditawarkan memungkinkan untuk lakukan dengan mudah oleh perempuan (women-friendly)

Hal-hal tersebut sangat penting untuk mengetahui bagaimana sumberdaya yang ada saat ini dapat mendukung keberlanjutan program tersebut di masa mendatang. Pada kebanyakan kasus, perempuan tidak mempunyai akses dan kontrol terhadap lahan. Mereka hanya dapat menggunakan lahan tersebut namun tidak mempunyai kekuatan untuk menentukan bagaimana lahan tersebut ingin mereka gunakan. Hakhak kepemilikan lahan lebih banyak jatuh di tangan laki-laki. Tentu saja kondisi seperti ini berbeda dari satu tempat ke tempat lainnya, yang dipengaruhi oleh aspek-aspek sosial budaya daerah-daerah yang bersangkutan. Pada struktur masyarakat bilineal yaitu masyarakat yang menganut perpaduan tradisi matrilineal dan patrilineal seperti di Sungai 
Telang misalnya, perempuan mempunyai akses dan kontrol pada lahan pertanian (khususnya sawah) lebih tinggi dibandingkan dengan laki-laki. Pengaruh budaya matrilineal yang kuat dalam sistem pewarisan lahan pertanian, memberikan kesempatan yang lebih besar kepada pihak perempuan (anak perempuan) untuk membuat keputusan bagaimana mereka ingin mengolah dan memanfaatkan lahan tersebut. Walau demikian, akses pemanfaatan dan hak guna lahan yang diberikan pada perempuan sifatnya masih sangat terbatas. Mereka hanya bisa mengelola lahan untuk kurun waktu tertentu, namun tidak mempunyai hak untuk menyewakan atau menjual lahan tersebut

Dari uraian-uraian di atas dapat kita lihat dengan jelas bahwa kebanyakan program-program pembangunan yang ada di daerah belum berperspektif Gender. Absennya komponen Gender dalam program pembangunan di daerah selama ini didasarkan pada alasan bahwa manfaat program dapat dinikmati oleh perempuan dan laki-laki dalam porsi yang sama, sehingga komponen Gender tidak perlu dipermasalahkan. Padahal dalam kenyataannya, banyak kendala-kendala yang menyulitkan bagi perempuan untuk memperoleh manfaat-manfaat tersebut secara seimbang sebagaimana yang diterima oleh laki-laki. Dengan demikian, setiap program harus mempertimbangkan komponen perempuan dan laki-laki sebagai dua faktor yang berpengaruh sama pentingnya terhadap keberhasilan suatu program. Hal ini dapat dilakukan secara sederhana dengan membuat data pilah pada setiap komponen program, mulai dari perencanaan kegiatan sampai pada tahap evaluasi (akhir).

Kita ambil salah satu contoh lain, misalnya program kegiatan yang paling sering diagendakan oleh Dinas Pertanian kabupaten, yaitu penyuluhan pertanian ke desa-desa. Program tersebut memberikan informasi baru mengenai sistem bertani dan pada saat yang sama memberikan kredit ringan untuk kelompok-kelompok tani supaya bisa mengimplementasikan pengetahuan baru tersebut di lahan mereka. Siapa yang terlibat dalam kelompok tani tersebut? Kebanyakan laki-laki. Contohnya, di desa Lubuk Kambing terdapat lebih dari 12 kelompok tani yang kebanyakan terbentuk dikarenakan adanya 'proyek' dadakan dari Pemerintah Kabupaten yaitu program P2WK Tanaman Karet dan 
Tanaman Palawija ${ }^{12}$. Program ini pada dasarnya menawarkan bantuan baik dalam bentuk bahan-bahan pertanian (bibit, pupuk, dll) ataupun pinjaman modal kepada kelompok tani agar dapat mengembangkan tanaman perkebunan di lahan pertanian yang dikelolanya. Kelompokkelompok tani tersebut dibentuk semata-mata sebagai prasyarat bagi masyarakat untuk dapat mengajukan permohonan bantuan dari program P2WK tersebut. Tidak ada satupun dari kelompok tersebut yang memiliki anggota campuran (laki-laki dan perempuan dalam satu kelompok). Ketika penyuluh pertanian datang ke desa untuk menyampaikan informasi, mereka mengundang keluarga-keluarga petani dalam suatu rapat di balai desa. Namun dengan anggapan bahwa laki-laki adalah kepala keluarga, maka hanya laki-laki yang hadir dalam pertemuan tersebut. Absennya perempuan dalam pertemuan tersebut sering luput dari perhatian pemberi program. Mereka beranggapan bahwa kondisi seperti ini tidak perlu dipermasalahkan karena dengan hadirnya petani laki-laki dianggap bahwa informasi telah disampaikan merata kepada sasaran program sebagaimana yang direncanakan dalam program penyuluhan pertanian tersebut.

Padahal pada prakteknya, kaum perempuanlah yang paling banyak mencurahkan waktunya dalam mengelola lahan pertanian di desa tersebut karena kaum laki-laki lebih banyak pergi ke hutan mencari kayu. Hasilnya, informasi mengenai cara-cara bertani ataupun mengenai sistem pemberian pinjaman keuangan tersebut tidak sampai pada 'pelaksana' programnya. Petani perempuan yang bekerja di ladang tetap menjalankan kegiatannya secara tradisional sebagaimana sebelumnya, tanpa informasi tambahan dari program pertanian tersebut.

Apakah hanya perempuan yang dirugikan jikahal ini terjadi? Mari kitalihat satu per satu siapa saja pihak yang dirugikan dengan program yang 'salah sasaran' tersebut. Pemerintah Daerah (Dinas pertanian atau perkebunan) mengeluarkan banyak dana untuk program tersebut, misalnya untuk membayar penyuluh, memberikan pinjaman modal, memberikan subsidi untuk pupuk, dll. Petani laki-laki di desa mengeluarkan tenaga dan waktu mereka untuk ikut rapat. Namun pada akhir pertemuan, mereka menyimpan informasi yang diterima untuk dirinya sendiri karena sulit 
untuk menjelaskan kembali secara utuh pada istrinya tentang apa yang disampaikan penyuluh di rapat tersebut. Istri atau anak perempuan usia produktif tetap mengelola lahan secara tradisional, karena informasi yang disampaikan penyuluh (ahli pertanian) tidak pernah sampai secara utuh pada mereka. Bibit tanaman yang diberikan tidak dikembangkan dengan baik atau dijual untuk mendapatkan uang (cash). Bahkan tidak sedikit diantara mereka yang mengkonsumsi bibit unggul yang diberikan, misalnya untuk tanaman kedelai. Pinjaman modal yang diterima bahkan banyak yang digunakan untuk keperluan di luar kegiatan pertanian, seperti membeli barang-barang keperluan sehari-hari (makanan, baju, alat-alat rumah tangga, dll). Kaum perempuan pada akhirnya juga ikut pusing memikirkan pengembalian kredit karena panennya tidak berhasil maksimal sebagaimana yang direncanakan oleh program tersebut ketika memberikan bantuan informasi dan modal usaha pada petani laki-laki. Mereka akhirnya tidak mau datang lagi ke pertemuan kelompok tani atau ke rapat penyuluhan serupa karena takut ditanyakan tentang keberhasilan tanaman yang dikembangkannya atau karena masih berhutang. Programprogram selanjutnya yang direncanakan oleh Pemerintah Daerah tentunya menjadi lebih sulit untuk dijalankan karena akan lebih banyak lagi petanipetani yang tidak (ingin) ikut terlibat dalam program kegiatan.

Tentu saja bukan jaminan hal yang sama tidak akan terjadi jika kaum perempuan juga ikut dilibatkan dalam program. Namun, setidaknya dapat mengurangi resiko kegagalan karena informasi program kegiatan memang disampaikan secara utuh kepada mereka yang melakukan kegiatan tersebut secara langsung di lapangan. Memang tidak semudah membalikkan telapak tangan untuk dapat membuat program yang sensitif Gender. Diperlukan perencanaan program yang matang, fasilitas dan dukungan dana yang tidak sedikit untuk dapat mengakomodasi partisipasi seimbang dari semua pihak, baik laki-laki dan perempuan. Untuk itu, perlu adanya upaya-upaya fasilitasi dan dukungan dari berbagai pihak termasuk LSM, peneliti atau lembaga lainnya yang memiliki Gender specialist, dalam proses penyusunan program-program pembangunan di daerah. Upaya fasilitasi bisa diberikan melalui dukungan finansial (dana), material (fasilitas informasi dan sumberdaya ahli) atau bentuk-bentuk kegiatan strategis yang langsung berhubungan 
dengan penerima manfaat program (pelatihan, pendampingan dan penguatan kelompok, dll). Dengan demikian para pengambil keputusan di daerah memperoleh dukungan penuh dan berbagai kalangan untuk mengupayakan perencanaan program-program daerahnya ke depan yang lebih sensitif Gender.

Dengan memasukkan komponen Gender ke dalam suatu program kegiatan, terdapat dua hal substansial yang dapat dicapai oleh program tersebut:

1. Distribusi manfaat yang merata diantara perempuan dan lakilaki dapat mendorong terciptanya kondisi ekonomi yang stabil di kalangan masyarakat bawah (grassroot level)

2. Memberikan peluang bagi program tersebut untuk lebih berkembang karena partisipasi perempuan berarti juga bertambahnya sumberdaya, meningkatnya kontrol dan efisiensi sehingga memungkinkan program tersebut dapat berkelanjutan dalam jangka panjang

Metode pengumpulan informasi seperti yang telah kita lakukan di atas dapat dijadikan salah satu cara untuk melakukan analisis Gender secara cepat dan sederhana terhadap program-program pembangunan di daerah. Ada berbagai macam cara untuk melakukan analisis Gender ${ }^{13}$, dari mulai yang sederhana sampai pada tingkat yang lebih kompleks. Namun pada prinsipnya, analisis Gender adalah perangkat yang digunakan untuk mengetahui sejauh mana rencana suatu program kegiatan dapat berdampak pada perempuan dan laki-laki. Dalam menganalisa Gender diperlukan pendalaman lebih jauh mengenai bagaimana identitas Gender mempunyai sudut pandang yang berbeda terhadap sesuatu hal serta bagaimana dinamika Gender yang ada pada kultur budaya setempat membentuk peran sosial, akses dan kontrol perempuan maupun laki-laki terhadap sumberdaya, fasilitas, kekuasaan dan pengambilan keputusan.

Analisis Gender juga bisa dilakukan bersama dengan masyarakat misalnya dengan menggunakan metode partisipatif seperti PAR (Participatory Action Research). Dengan metode partisipatif, masyarakat menjadi pengambil keputusan utama dalam menentukan perencanaan, pelaksanaan dan pengawasan program kegiatan, sehingga analisis Gender 
yang dilakukan didasarkan pada faktor-faktor lokal yang berkembang di wilayah tersebut. Hal ini sangat berguna untuk memunculkan kesadaran Gender di kalangan yang lebih luas. Tentunya, diperlukan bantuan dari fasilitator-fasilitator Gender yang dapat membantu mereka mengenali dan menggali lebih jauh mengenai faktor-faktor lokal tersebut. Beberapa teknik yang dapat digunakan untuk memfasilitasi kelompok-kelompok masyarakat akan dibahas lebih lanjut pada bagian selanjutnya. 



\section{BAB 3 \\ Bagaimana Memfasilitasi Kelompok Perempuan?}

Sebagai bagian yang tidak terpisahkan dari upaya mengenalkan Gender di masyarakat adalah proses fasilitasi kelompok, atau lebih khusus lagi adalah kelompok perempuan.

Hal yang umum ditemukan pada kelompok perempuan yaitu mereka lebih aktif terlibat dalam diskusi kelompok yang homogen, yaitu kelompok perempuan yang terpisah dari laki-laki. Biasanya hal ini berkaitan dengan perasaan nyaman karena bebas dari tekanan sosial (stereotype) dan merasa memiliki kesempatan yang lebih besar untuk didengarkan oleh anggota kelompok lainnya dengan tidak adanya perbedaan posisi. Pada kebanyakan kasus, mengelompokkan perempuan dan laki-laki pada kelompok yang berbeda akan sangat membantu proses fasilitasi, terutama jika berkaitan dengan isu Gender. Tentu saja bukan tidak mungkin dapat dilakukan fasilitasi pada kelompok campuran, selama perempuan dapat mengekspresikan pendapatnya secara bebas. Jika tidak, maka kelompok perempuan sebaiknya dibuat terpisah dari kelompok laki-laki.

Pengalaman memfasilitasi kelompok petani perempuan di Jambi menunjukkan perlunya menerapkan pendekatan yang berbeda untuk setiap komunitas. Misalnya, pada komunitas asli Jambi yang masih lekat 
dengan budaya patriarkhi dan kelompok masyarakat keturunan JambiMinangkabau (yang memiliki tradisi bilineal), mereka lebih terbuka dan dinamis jika berada pada kelompok homogen (hanya perempuan). Kebanyakan dari mereka malu dan kurang percaya diri jika harus berbicara di dalam forum campuran. Sementara itu, pada kelompok masyarakat migran (pendatang) dinamika kelompok terlihat lebih baik pada kelompok campuran. Diskusi kelompok dalam kelompok tersebut menjadi lebih hidup, dimana interaksi perempuan dan laki-laki berjalan seimbang dalam forum diskusi sehingga memunculkan ide-ide yang lebih beragam.

Dengan mengenali karakter kelompok dan kondisi lingkungan setempat, akan lebih mudah bagi kita untuk memfasilitasi dan menggali informasi yang diinginkan dari sudut pandang yang berbeda, yaitu dari kelompok perempuan, kelompok laki-laki dan kelompok campuran. Dinamika kelompok dapat dijadikan titik awal bagi kita untuk menggali lebih jauh bagaimana struktur sosial setempat membentuk peran Gender di lingkungan tersebut.

Perlu diingat bahwa Gender selalu menjadi isu sensitif pada saat pertama kali diperkenalkan pada suatu komunitas. Untuk itu, diperlukan kehatihatian untuk mempertimbangkan adanya perbedaan norma-norma lokal yang berlainan dari satu tempat ke tempat lainnya.

Pengalaman menunjukkan bahwa topik Gender akan lebih mudah untuk didiskusikan dengan kelompok-kelompok baru jika topik ini digabungkan dengan pemberian informasi lain yang cenderung tidak terlalu sensitif atau yang dianggap lebih praktis. Misalnya informasi tentang hukum, politik, pendidikan, perkawinan dan topik informatif lainnya. Hal ini dapat menjadi pintu pembuka awal untuk mencairkan suasana, terutama pada komunitas yang masih tertutup terhadap isu-isu kesetaraan Gender. Yang paling sering berhasil membawa isu Gender ke permukaan adalah topik yang berkaitan dengan hukum-hukum perkawinan, kesehatan keluarga, pendidikan anak dan isu kekerasan dalam rumah tangga. Berangkat dari pembahasan topik-topik tersebut kita bisa memperoleh gambaran secara umum mengenai kultur setempat dan menggali lebih banyak informasi 
mengenai bagaimana hubungan (relasi) dan kedudukan perempuan dan laki-laki di dalam masyarakat tersebut.

\subsection{Fasilitator}

Fasilitator, sebagaimana kata itu sendiri, berfungsi hanya memfasilitasi dan memberikan bantuan untuk memperlancar proses komunikasi sekelompok orang yang melakukan kegiatan bersama. Pada dasarnya seorang fasilitator harus berada pada posisi netral dan sejauh mungkin tidak ada keberpihakan. Fasilitator hanya membantu individu dan kelompok untuk menemukan kesepahaman dan memberikan jalan untuk pemecahan masalah bersama melalui bantuan metode dan alat fasilitasi.

Fasilitator bukan narasumber. Oleh karena itu, tugas fasilitator bukan memberi nasehat dan tidak merasa lebih tahu mengenai topik dan masalah yang dibahas bersama kelompok. Seorang fasilitator yang baik adalah menggali sebanyak mungkin informasi, ide dan pendapat dari kelompok, yang selanjutnya mengelompokkan informasi-informasi tersebut menjadi lebih terstruktur dan mudah dimengerti oleh semua orang yang ada dalam kelompok tersebut.

Berikut ini adalah beberapa hal yang harus dimiliki oleh seorang fasilitator antara lain:

- Fasilitator lebih banyak mendengarkan dan menyimak ide-ide yang dikemukakan setiap anggota kelompok.

- Fasilitator tidak berpihak (diupayakan senetral mungkin) terhadap substansi maupun pihak.

- Fasilitator menyadari bahwa setiap anggota kelompok mempunyai asumsi berbeda dalam memandang sesuatu dan mengakui bahwa setiap asumsi tersebut adalah penting.

- Fasilitator tidak menghakimi pendapat yang dikemukakan. Karena tidak ada ide atau pendapat yang benar atau salah. Semua pendapat berkontribusi terhadap pemecahan masalah bagi kelompok. Semakin banyak perbedaan pendapat, maka semakin banyak solusi alternatif yang dapat dipilih oleh kelompok. 
- Fasilitator lebih banyak bertanya untuk menggali ide-ide dari anggota kelompok.

- Fasilitator harus lebih banyak mencermati dan observasi. Hal ini untuk menjamin semua anggota merasa dilibatkan dalam proses. Salah satu cara adalah mengulang kembali pertanyaan atau pernyataan dari seorang anggota ke dalam bahasa yang lebih mudah dimengerti bagi anggota kelompok lainnya, termasuk anggota yang pasif.

- Fasilitator berpikir positif dan memberi motivasi pada seluruh anggota untuk mengeluarkan pendapatnya, terutama jika terdapat individu-individu dominan dalam kelompok.

Kelihaian seorang fasilitator teruji saat harus menghadapi konflik perbedaan pendapat diantara anggota kelompok. Beberapa hal yang dapat dilakukan fasilitator jika dihadapkan pada kondisi tersebut:

- Berusaha tetap netral, sebisa mungkin tidak berpihak pada salah satu pihak.

- Berusaha memberikan energi positif pada kelompok dan menjaga hubungan baik pihak bersengketa dengan cara memberikan sudut pandang yang baik dari satu pihak terhadap pihak lainnya.

- Mengubah sengketa menjadi proses berunding dengan cara mengerucutkan ide-ide yang sangat berbeda menjadi satu daftar yang terstruktur. Dengan demikian, masing-masing pihak yang bersengketa dapat melihat dengan jelas apa yang menjadi pokok perbedaannya dan mencari peluang untuk berkompromi untuk mencapai tujuan utama.

- Mengubah perbedaan pendapat menjadi alternatif pemecahan masalah, sehingga masing-masing pihak tidak merasa dimenangkan atau dikalahkan.

\subsection{Apakah Fasilitator Gender Harus Perempuan?}

Tentu saja jawabannya tidak. Masalah ketimpangan Gender bukan hanya masalah perempuan. Membahas tentang Gender bukan berarti 
memisahkan hal-hal yang dianggap 'masalah perempuan' dengan realitas kehidupan lainnya, melainkan mencoba memberikan dimensi dan cara pandang baru terhadap posisi perempuan dan laki-laki agar sejajar kedudukannya di dalam masyarakat.

Untuk itu, fasilitator dalam program Gender tidak harus perempuan. Yang terpenting adalah seseorang yang mempunyai kemampuan utuh seorang fasilitator.

Namun demikian, pengalaman menunjukkan bahwa pada komunitaskomunitas tradisional tertentu, jenis kelamin fasilitator memang sangat berpengaruh terhadap keberlangsungan berjalannya proses kegiatan. Idealnya pada komunitas tradisional yang sama sekali belum pernah tersentuh 'isu Gender', fasilitator dipilih perempuan jika memungkinkan. Beberapa alasan yang ditemukan di lapangan antara lain:

- Terutama untuk yang berusia masih muda, fasilitator laki-laki cenderung merasa sungkan (bahkan terkadang malu-malu) untuk membahas secara terbuka topik-topik tertentu yang berkaitan dengan problematika perempuan (terutama yang berkaitan dengan fungsi-fungsi biologis).

- Pada komunitas tradisional tertentu sulit diterima jika laki-laki 'dari luar' berbicara hanya berdua dengan perempuan.

- Pada kebanyakan kasus, perempuan lebih terbuka terhadap perempuan lainnya (fasilitator) dan merasa lebih nyaman bertanya tentang banyak hal tanpa merasa malu, takut melanggar tradisi atau kepantasan, dan lain sebagainya.

Kondisi ini tentunya bukan menjadi alasan untuk tidak memilih laki-laki sebagai fasilitator. Pada kondisi-kondisi dan tempat tertentu, fasilitator laki-laki bisa pula memberi pengaruh positif terhadap keberlangsungan program. Terutama pada program-program yang tidak mengkhususkan kegiatannya untuk Gender awareness. Artinya Gender hanya merupakan salah satu aspek yang mendukung program yang lebih besar, seperti halnya yang ada pada program CAPRi, yang lebih berfokus pada sumberdaya alam, hak-hak properti dan penguatan aksi kelompok. 


\subsection{Mengenal Karakter Kelompok}

Mengambil pengalaman dari fasilitasi kelompok yang ada di Sungai Telang dan Lubuk Kambing, dapat terlihat adanya 4 karakter individu dalam kelompok yang digolongkan berdasarkan kontribusinya terhadap aksi kolektif:

1. kelompok individu yang pasif, sama sekali tidak peduli dan tidak aktif dalam kelompok. Hanya namanya saja yang tercantum dalam daftar anggota tetapi tidak pernah aktif terlibat.

2. kelompok individu yang hanya berkontribusi kecil sekali, misalnya hanya datang ke pertemuan tapi tidak memberi komentar atau pendapat. Hanya datang untuk tujuan pribadi, misalnya menjual dagangannya kepada anggota lain.

3. kelompok individu yang datang ke pertemuan lebih sering, membayar iuran kelompok, ikut mendengarkan tapi tidak banyak bersuara atau mengeluarkan pendapat.

4. kelompok individu yang aktif, menanggung semua tanggung jawab, mendedikasikan waktu dan tenaga untuk kelompok dan aksi kolektifnya. Biasanya individu seperti ini yang kemudian akan menjadi kelompok 'elite' di waktu-waktu mendatang.

Dengan mengenali karakter-karakter yang ada di kelompok, proses fasilitasi akan berjalan lebih mudah. Fasilitator dapat menerapkan strategi lebih baik dari awal untuk menjamin semua anggota kelompok dapat berpartisipasi sesuai dengan kapasitasnya masing-masing. Misalnya, lebih banyak bertanya dan menggali ide-ide dari kelompok yang pasif sehingga mereka terpacu untuk lebih memberi perhatian pada aktivitas kelompok karena merasa tetap aktif dilibatkan dalam proses. Dalam banyak kasus, dominasi dari kelompok individu aktif lambat laun bisa mematikan dinamika kelompok. Akibatnya, ide-ide kelompok tidak tergali secara maksimal dan tidak terjadi proses belajar bersama, melainkan hanya menciptakan satu atau dua orang individu dominan yang memegang kendali kelompok. 


\subsection{Adakah Hal-hal Lain yang Perlu Diantisipasi jika Fasilitasi Telah Berjalan Sukses Saat Ini?}

\subsubsection{Ketergantungan yang Tinggi dari Kelompok Dampingan terhadap Fasilitator}

Setelah sekian lama bekerja dengan kelompok dampingan, fasilitator cenderung mempunyai ikatan personal yang lebih dalam dibandingkan dengan waktu pertama kali mereka berinteraksi. Seiring berjalannya waktu, banyak fasilitator yang tidak lagi berada dalam posisi netral. Ada keberpihakan yang cenderung lebih pada satu pihak dibanding pihak lainnya. Sehingga pada saat kelompok dampingan memiliki tujuan dan keinginan tertentu, fasilitator secara otomatis berpihak pada mereka. Pada akhirnya, fasilitator ikut sibuk mencarikan solusi daripada memfasilitasi kelompok tersebut untuk menemukan jalan keluar sendiri dari permasalahannya. Akibatnya, permasalahan kelompok berpindah ke pundak fasilitator. Hal ini dapat mematikan dinamika kelompok, oleh karena itu perlu dilakukan antisipasi antara lain:

a. Pergantian (rolling) fasilitator dalam kurun waktu tertentu. Tentunya pergantian harus dilakukan pelan-pelan dan gradual, tidak langsung. Fasilitator pengganti harus mulai terlibat dalam proses (sebagai pengamat atau observer) sebelum memulai mengambil alih, sehingga proses belajar dalam kelompok tidak terganggu.

b. Menetapkan rencana yang jelas dari sejak awal kegiatan. Rencana tersebut harus memuat dengan jelas siapa-siapa saja yang bertanggung jawab terhadap satu proses kegiatan tertentu. Dalam rencana tersebut harus jelas terlihat bahwa fasilitator tidak terlibat dalam proses kegiatan melainkan hanya membantu mereka membagi-bagi peran diantara anggota. Dalam kaitannya dengan aksi kolektif yang masih berlangsung diantara kelompok perempuan di Jambi, beberapa tahapan kegiatan yang dapat difasilitasi antara lain:

- Menggali ide: Fasilitator membantu kelompok menggali ide sebanyak-banyaknya dari setiap individu yang ada terlibat dalam proses kegiatan. 
- Membuat rancangan kegiatan: Fasilitator membantu mengelompokkan ide tersebut ke dalam suatu matrik terstruktur dimana setiap anggota kelompok dapat dengan mudah mengenali dan memahami ide-ide tersebut. Anggota kelompok harus bisa dengan mudah melihat ide mana saja yang mungkin dilakukan dan mana yang tidak. Sehingga ide tersebut bisa mengerucut menjadi satu ide besar untuk tujuan bersama. Selanjutnya, fasilitator dapat membantu kelompok menentukan siapa mengerjakan apa, kapan, bagaimana dan apa hasil yang ingin dicapai. Dengan demikian ada target kelompok yang jelas dalam kurun waktu tertentu.

- Aksi: Fasilitator mendampingi pelaksanaan program kegiatan. Hal ini mencakup identifikasi masalah yang muncul selama proses kegiatan berlangsung bersama dengan kelompok, mengelompokkan masalah-masalah yang ada menjadi lebih mudah dibahas dan membantu kelompok berkomunikasi satu sama lain untuk mencari jalan keluar dari masalah tersebut bersama-sama.

- Monitoring: Fasilitator membantu kelompok menjaga proses kegiatan berlangsung simultan. Seringkali, pada kurun waktu tertentu kelompok tidak lagi mengikuti alur proses yang mereka rencanakan pada awal kegiatan. Jika hal ini terjadi, fasilitator dapat mengingatkan kelompok dengan cara merefleksi kembali proses-proses yang telah mereka lalui bersama sehingga mereka bisa menetapkan langkah-langkah yang harus diambil untuk menjaga proses kegiatan berlangsung sampai ke tujuan yang direncanakan.

- Evaluasi: Fasilitator membantu kelompok mengevaluasi hasil kegiatan. Mengidentifikasi apa yang perlu diubah, ditingkatkan, dikurangi atau dipertahankan pada kegiatan selanjutnya.

c. Membuat rencana yang matang dengan kelompok untuk kegiatankegiatan tindak lanjut pada saat program kegiatan ini berakhir. Fasilitasi untuk penguatan kelompok harus memiliki exitstrategy yang jelas: kapan dan bagaimana kegiatan kelompok bisa berjalan tanpa adanya fasilitator dari luar. Sehingga ketika program pendampingan 
berakhir, kelompok telah terbiasa memfasilitasi proses sendiri (tanpa fasilitator). Fasilitator dapat melakukan tandem (mengikutkan salah satu anggota kelompok sebagai co-fasilitator secara bergiliran) pada setiap pertemuan kelompok. Seluruh anggota kelompok harus diberi kesempatan yang sama untuk bereksperimen dalam memfasilitasi forum. Informasi-informasi mengenai teknik fasilitasi, dengan demikian, perlu juga disampaikan dan dipraktekkan bersama dengan anggota kelompok selama berlangsungnya proses pendampingan kelompok.

\subsubsection{Fasilitator Berubah menjadi Guru dan Narasumber}

Setelah sekian lama mengikuti proses, banyak fasilitator yang secara tidak sadar menjadi merasa lebih banyak tahu dan pada akhirnya lebih banyak menggurui dan memberi nasehat daripada membantu menggali ide-ide dan pendapat kelompok. Fasilitator mulai sibuk memberikan ide-idenya sendiri dan menjadi tidak sabar dalam memandu proses. Terutama untuk fasilitator yang juga mempunyai keahlian di bidang tertentu, dia menjadi tidak sabar untuk memberitahu apa yang harus dilakukan atau tidak bisa dilakukan oleh kelompok berdasarkan pengetahuan yang dia miliki. Fasilitator berubah jadi narasumber yang lupa untuk menggali potensi kelompok dalam menentukan apa yang bisa atau tidak bisa dilakukan oleh kelompok tersebut. Padahal tidak selalu pengetahuan atau pengalaman yang dimiliki seorang ahli akan sesuai dengan kondisi lokal. Bisa jadi solusi yang diberikan malah menutup kemungkinan ide yang muncul orisinil dari salah satu individu karena sudah minder duluan dihadapkan dengan 'sang ahli'.

Jika hal seperti ini berlangsung lebih lama, proses yang terjadi selanjutnya adalah mematikan kreativitas dan ide-ide kelompok. Tidak jarang pada akhirnya kelompok dampingan hanya menjadi murid yang baik atau pesuruh yang kerja bakti melakukan ide-ide atau asumsi yang dilontarkan fasilitator.

Untuk menghindari hal tersebut, terdapat dua hal yang dapat dilakukan: 
1. Pada saat merumuskan tujuan dan sasaran kegiatanyang direncanakan, fasilitator membantu kelompok untuk juga merumuskan dan menetapkan indikator-indikator pengukur keberhasilan suatu tahapan kegiatan tertentu. Sehingga, mereka sendiri dapat melihat dengan jelas garis pembatas yang menunjukkan kapan dan bagaimana proses yang sedang mereka jalani dapat dikatakan mencapai target yang diinginkan atau masih jauh tertinggal dari rencana awal yang mereka sepakati sebelumnya.

2. Fasilitator hendaknya juga mempunyai jadwal berkala untuk mengevaluasi kegiatan fasilitasi yang telah dilakukannya bersama kelompok. Dengan demikian dapat diperoleh gambaran yang lebih jelas mengenai kebutuhan-kebutuhan kelompok akan informasiinformasi tambahan yang mereka perlukan untuk kegiatan berikutnya. Dengan memiliki daftar kebutuhan-kebutuhan kelompok, fasilitator juga dapat mengantisipasi untuk tidak memberikan 'solusi instan' bagi permasalahan kelompok melalui 'ceramahnya' melainkan mempersiapkan strategi, alat dan teknik fasilitasi yang sesuai untuk menggali solusi-solusi yang ditawarkan oleh masing-masing individu kelompok tersebut.

\subsubsection{Fasilitator menjadi Misionaris}

Kenyataannya kebanyakan fasilitator yang bekerja dengan kelompokkelompok masyarakat adalah seseorang yang dibayar oleh suatu program. Tentunya program tersebut terikat kontrak dengan pihak-pihak yang memberi fasilitas dana. Bukan rahasia jika setiap penyandang dana (donor) mempunyai agenda tertentu. Setelah berjalan waktu lama, seorang fasilitator mulai dapat mengukur apakah kegiatan kelompok mencapai target atau titik tertentu yang diharapkan dari program donor atau tidak. Jika semua berjalan lancar, fasilitator biasanya terlalu bersemangat dan ingin menjaga proses belajar kelompok berada dalam posisi yang sama atau lebih baik. Hal ini tidak memberi ruang bagi kelompok untuk berjalan dinamis, karena setiap ada kesulitan yang berpotensi menghambat proses mencapai tujuan atau membelok dari tujuan yang diharapkan program (padahal mungkin berpotensi memberikan hasil yang lebih baik) fasilitator segera membelokkan kemudinya kembali ke tujuan yang (diinginkan program) semula. Fasilitator berubah menjadi 
misionaris yang gigih memegang kemudi, dan kelompok dampingan menjadi pengikut setia.

Hal seperti ini sering luput dari perhatian pengelola program-program yang berhubungan dengan pendampingan kelompok di masyarakat. Karena lebih terfokus dengan 'hasil akhir' yang telah tertulis dari program kegiatan tersebut, mereka lupa bahwa yang terpenting dari kegiatan pendampingan kelompok adalah proses belajar yang terjadi selama kegiatan berlangsung. Tentu saja bukan berarti bahwa kita tidak mengharapkan kegiatan tersebut 'mencapai hasil' yang baik sesuai dengan rentang waktu yang direncanakan. Namun perlu diingat bahwa tolok ukur keberhasilan suatu kegiatan bukan hanya dilihat dari besarnya target atau sasaran kegiatan yang dicapai kelompok, tetapi juga dapat dilihat dari bagaimana kelompok tersebut mampu memfasilitasi dirinya sendiri dan melanjutkan proses belajar bersama pasca pendampingan. Secara sederhana dapat dikatakan bahwa kelompok tersebut menjadi lebih 'berdaya', lebih kuat dan mampu mengatasi kendala-kendala yang ada secara mandiri. Sayangnya, perubahan pada tingkat kemampuan kelompok (empowerment skills) yang terjadi pada akhir kegiatan, seringkali tidak dimasukkan oleh 'perencana program' sebagai komponen pengukur keberhasilan suatu kegiatan pendampingan (Colfer, 2006. komunikasi personal).

\subsubsection{Munculnya 'Selebritis' dalam Kelompok}

Selain masalah-masalah yang muncul dari fasilitator, pada kebanyakan pendampingan kelompok yang berhasil akan muncul 'masalah elite'. Dengan semakin banyaknya informasi, pelatihan dan fasilitas yang diterima kelompok, akan muncul beberapa orang dalam kelompok yang akan berproses lebih cepat dari anggota kelompok lainnya. Terutama pada kelompok individu yang berani mengeluarkan pendapat, memiliki tingkat pendidikan atau status sosial lebih tinggi dari kebanyakan anggota lainnya dan mempunyai jaringan lebih luas, besar kemungkinan mereka akan cepat dikenal oleh kalangan di luar lingkungan kelompoknya. Setelah beberapa waktu individu-individu seperti ini akan sibuk memenuhi undangan seminar, lokakarya, jejak pendapat atau diundang menjadi pembicara di pertemuan-pertemuan formal, diundang jadi 
narasumber di radio, media, dsb. yang pada akhirnya terlalu sibuk di luar dan tercabut dari kelompoknya sendiri. Dia tidak lagi mengikuti perkembangan kelompok, tidak lagi ikut berproses dengan anggota lainnya, dan sibuk dengan promosi dirinya sendiri. Pada kebanyakan aksi kolektif, mereka menjadi lebih dominan di dalam kelompok dan menutup kesempatan bagi anggota kelompok lainnya untuk memperoleh manfaat yang sama dari aksi kolektif yang semula mereka rencanakan untuk kepentingan bersama. Kondisi seperti ini juga terjadi di Tanjabbar. Beberapa orang perempuan aktif yang berasal dari kelompok perempuan di Tanjabbar, berkali-kali memperoleh fasilitas dari pemerintah daerah dalam bentuk kesempatan pelatihan, menghadiri pameran, seminar, dan sejenisnya termasuk juga bantuan dana. Dengan semakin berkembangnya kemampuan mereka, di sisi lain, perannya dalam kelompok menjadi lebih dominan. Kondisi seperti ini perlahan melemahkan kekuatan kelompok mereka. Usaha yang pada awalnya berbentuk aksi kolektif cenderung berkembang menjadikan anggota kelompoknya sebagai buruh yang dibayar ${ }^{14}$.

Di kalangan LSM, fenomena tersebut dikenal dengan istilah 'selebritis' kelompok. Jika kondisi seperti ini terjadi pada kelompok dampingan perempuan, tentunya juga tidak sejalan dengan tujuan semula memberdayakan perempuan. Karena anggota perempuan lainnya menjadi tidak berdaya (atau malah terpedaya) dengan adanya dominasi dari elite-elite tertentu di dalam kelompok.

Hal seperti ini harus menjadi perhatian fasilitator sejak awal kegiatan berlangsung. Beberapa hal yang dapat dilakukan sebagai tindakan antisipasi antara lain ${ }^{15}$ :

- Fasilitator membantu kelompok untuk merumuskan beberapa aturan dasar di dalam kelompok yang disepakati seluruh anggota, sejak awal kegiatan. Dalam aturan dasar tersebut dapat dimasukkan komponen tentang distribusi manfaat yang merata di antara anggota kelompok.

- Mendistribusikan informasi secara merata ke setiap anggota kelompok mengenai kegiatan-kegiatan tersebut dan membuat matrik kegiatan bersama kelompok, untuk menentukan secara bergiliran siapa saja 
yang mewakili kelompok untuk menghadiri kegiatan-kegiatan di luar. Hal ini bisa dilakukan secara sederhana dengan menuliskan daftar nama anggota kelompok dan daftar kegiatan atau peluang yang ditawarkan pada kelompok tersebut, di dalam karton besar. Sehingga, setiap individu dapat dengan mudah melihat peluang apa saja yang telah dimanfaatkan kelompok dan siapa yang mewakili mereka dalam kegiatan tersebut. Dengan demikian tidak hanya orang-orang tertentu yang selalu mengikuti perkembangan di luar kelompok (seminar, lokakarya, pameran, dll) melainkan secara bergiliran.

- Menerapkan sistem tandem ketika kelompok diminta untuk berpartisipasi dalam suatu kegiatan tertentu. Artinya, menggabungkan anggota 'elite' dengan anggota yang kurang 'progresif' dan meminta mereka untuk menghadiri kegiatan tersebut bersama-sama. Karena seringkali, dengan adanya anggota kelompok yang dominan, membuat individu lainnya dalam kelompok tersebut menjadi kurang percaya diri ketika diminta menghadiri kegiatan di luar kelompok. Dengan alasan 'tidak ada anggota lain yang bersedia' untuk mewakili kelompok, maka individu yang dominan secara otomatis akan selalu mendapat tempat untuk kegiatan-kegiatan tersebut. Melalui sistem tandem ini, juga dapat mempercepat proses capacity building diantara individu-individu dalam kelompok karena setiap anggota kelompok mendapatkan kesempatan yang sama dan mempunyai percepatan yang seimbang dalam berproses.

\section{Penutup}

Kesulitan untuk memberdayakan perempuan bukan saja disebabkan oleh kurangnya dukungan lingkungan, terbatasnya fasilitas maupun sistem yang mendukung kemajuan perempuan, akan tetapi juga rendahnya motivasi dari perempuan itu sendiri. Kesulitan mengenali atau bahkan menyadari adanya ketidakadilan Gender yang terjadi di sekeliling mereka, merupakan salah satu faktor penting yang menyebabkan lemahnya keinginan dari perempuan untuk melakukan perubahan. Untuk 
itulah, peningkatan kesadaran Gender merupakan langkah awal yang harus diambil dalam upaya peningkatan kapasitas perempuan sebelum melakukan langkah-langkah selanjutnya yang lebih kompleks.

Menyadari dan mengenali, bukan dipaksa untuk mengenali atau dipaksa sadar bahwa mereka diperlakukan tidak adil, memerlukan proses yang panjang. Untuk itulah diperlukan fasilitasi yang simultan dan berkelanjutan terhadap kelompok perempuan agar secara perlahan-lahan menyadari ketimpangan Gender yang ada di sekitar mereka. Hal yang perlu ditekankan adalah bahwa Gender merupakan hasil dari konstruksi sosial masyarakat yang sangat mungkin dilakukan perubahan. Salah satu cara yang dapat ditempuh adalah melalui fasilitasi aksi kolektif yang secara langsung bersentuhan dengan isu Gender.

Kelompok perempuan secara alami mempunyai ikatan yang lebih kuat dibandingkan dengan kelompok laki-laki. Hal ini disebabkan karena ketergantungan antar individu perempuan dengan perempuan lainnya mempunyai ikatan emosional yang lebih kuat dibandingkan dengan lakilaki. Untuk itulah kelompok perempuan biasanya lebih homogen dari kelompok laki-laki. Jumlah kelompok perempuan yang terlibat dalam kegiatan sosial lebih banyak dibandingkan dengan laki-laki, dan karena kegiatan aksi kolektif mengelola sumberdaya alam termasuk kategori kegiatan sosial (tidak memberikan nilai ekonomi langsung secara material) maka lebih cenderung dapat berjalan dalam kelompok perempuan. Oleh karena itu, Gender awareness merupakan komponen yang sangat penting dalam memfasilitasi kelompok perempuan yang terlibat dalam aksi kolektif, untuk lebih meningkatkan kapasitas kelompoknya dan kualitas individu-individu yang tergabung di dalamnya.

Dengan pembagian peran Gender yang seimbang, perempuan memiliki peluang yang lebih besar, kesempatan yang lebih luas untuk dapat terlibat dalam berbagai kegiatan publik termasuk aksi kolektif. Hal ini tentunya akan mendukung positif ke arah tujuan pemberdayaan perempuan yaitu meningkatkan akses dan kontrol terhadap sumberdaya dan mendapatkan manfaat dari sumberdaya tersebut bagi kepentingan masyarakat yang hidup di sekitarnya. 


\section{CATATAN AKHIR}

$1 \quad$ BPS. 2003. Statistik Kesejahteraan Rakyat 2003. Jakarta.

2 Diambil dari artikel 'Girls top of the class worldwide'. BBC News. September 16, 2003. Diakses pada 18 Mei 2006 via http://news.bbc. co.uk.

3 Lihat Sulivan, N. 1991. 'Gender and Politics in Indonesia,' dalam Maila Stivens (ed.), Why Gender Matters in Southeast Asia, Clayton: Monash Centre of Southeast Asian Studies. p.61-86.

4 Dinas Sosial dan Pemberdayaan Masyarakat Tanjabbar. Data Terpilah Gender Kabupaten Tanjung Jabung Barat. Sub Dinas Pemberdayaan Perempuan dan DKK, Dinas Sosial dan Pemberdayaan Masyarakat Kabupaten Tanjung Jabung Barat. Jambi.

$5 \quad$ Pasal 65 Ayat (1) RUU Pemilu 2004 berbunyi: "Setiap partai politik peserta pemilu dapat mengajukan calon anggota DPR, DPRD Provinsi, dan DPRD Kabupaten/Kota untuk setiap daerah pemilihan dengan memperhatikan keterwakilan perempuan sekurangkurangnya 30 persen.”

6 International Labor Organization. 2002. Key Indicators of Labour Market (KILM) 2001-2002 edition. Geneva: United Nations.

7 Data diambil dari data hasil workshop gender di desa Lubuk Kambing pada bulan Mei 2005. 
8 Reppucci, N.D., \& Haugaard, J.J. (1993). Problems with child sexual abuse prevention programs. In R. Gelles \& D. Loseke (Eds.), Current controversies in family violence (pp. 306-323). Beverly Hills: Sage.

9 Goldner, V., Penn, P., Sheinberg, M., \& Walker, G. (1990). Love and violence: Gender paradoxes in volatile attachments. Family Process: 29. p. 343-364.

10 Heise L, Ellsberg M, Gottemoeller M. 1999. "Ending violence against women.” Population Reports. Series L, No. 11. Baltimore, Maryland: Population Information Program, Johns Hopkins University School of Public Health. Cited in WHO. 2002 World Report on Violence and Health. Geneva: WHO.

11 Agrawal, B.2000. Conceptualising environmental collective action: why gender matters. Cambridge Journal of Economics: 24.p 283310.

12 Beberapa informasi mengenai kelompok tani di Jambi diambil dari hasil studi tim CAPRi (Neldysavrino, Yentirizal dan Yulia Siagian) yang masih berlangsung di Desa Lubuk Kambing dan Sungai Telang.

13 Salah satu metode analisis gender dapat dilihat dari: DFID Sustainable Livelihoods Guidance Sheets, Bagian 4.3. melalui akses internet www.livelihoods.org.

14 Morgan, B., Komarudin, H. and Siagian Y.L. (in prep). The evolution of woman groups in making collective action effective in Tanjabbar district. CIFOR, Bogor.

15 Beberapa hal yang tercantum dalam bagian ini diambil dari komunikasi personal dengan Dr. Carol J. Colfer (2006). CIFORIndonesia. 
Center for International Forestry Research (CIFOR) adalah lembaga penelitian kehutanan internasional terdepan, yang didirikan pada tahun 1993 sebagai tanggapan atas keprihatinan dunia akan konsekuensi sosial, lingkungan dan ekonomi yang disebabkan oleh kerusakan dan kehilangan hutan. Penelitian CIFOR ditujukan untuk menghasilkan kebijakan dan teknologi untuk pemanfaatan dan pengelolaan hutan yang berkelanjutan, dan untuk meningkatkan kesejahteraan masyarakat di negara-negara berkembang yang bergantung kepada hutan tropis untuk kehidupannya. CIFOR adalah salah satu di antara 15 pusat yang didukung oleh Consultative Group on International Agricultural Research (CGIAR). Berpusat di Bogor, Indonesia, CIFOR mempunyai kantor regional di Brazil, Burkina Faso, Kamerun dan Zimbabwe, dan bekerja di lebih dari 30 negara di seluruh dunia.

\section{Donatur}

CIFOR menerima pendanaan dari pemerintah, organisasi pembangunan internasional, yayasan swasta dan organisasi regional. Pada tahun 2005, CIFOR menerima bantuan keuangan dari Australia, Asian Development Bank (ADB), Belgia, Brazil,Canada, China, Centre de coopération internationale en recherche agronomique pour le développement (CIRAD), Cordaid, Conservation International Foundation (CIF), European Commission, Finland, Food and Agriculture Organization of the United Nations (FAO), Ford Foundation, France, German Agency for Technical Cooperation (GTZ), German Federal Ministry for Economic Cooperation and Development (BMZ), Indonesia, International Development Research Centre (IDRC), International Fund for Agricultural Development (IFAD), International Tropical Timber Organization (ITTO), Israel, Italy, The World Conservation Union (IUCN), Japan, Korea, Netherlands, Norway, Netherlands Development Organization, Overseas Development Institute (ODI), Peruvian Secretariat for International Cooperation (RSCl), Philippines, Spain, Sweden, Swedish University of Agricultural Sciences (SLU), Switzerland, Swiss Agency for the Environment, Forests and Landscape, The Overbrook Foundation, The Nature Conservancy (TNC), Tropical Forest Foundation, Tropenbos International, United States, United Kingdom, United Nations Environment Programme (UNEP), World Bank, World Resources Institute (WRI) dan World Wide Fund for Nature (WWF). 

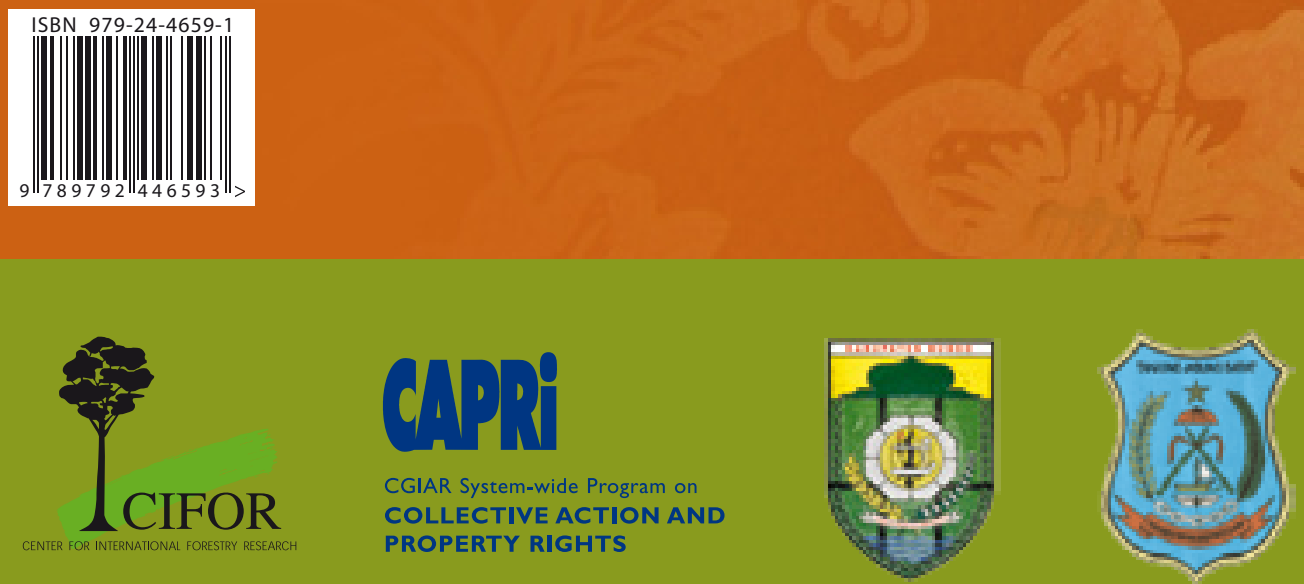